\title{
Dodging the Taxman: Firm Misreporting and Limits to Tax Enforcement
}

\section{Citation}

Carrillo, Paul, Dina Pomeranz, and Monica Singhal. "Dodging the Taxman: Firm Misreporting and Limits to Tax Enforcement." Harvard Business School Working Paper, No. 15-026, October 2014. (Note: Previously circulated as "Tax Me if You Can: Firm Misreporting Behavior and Evasion Substitution.")

\section{Permanent link}

http://nrs.harvard.edu/urn-3:HUL.InstRepos:13365391

\section{Terms of Use}

This article was downloaded from Harvard University's DASH repository, and is made available under the terms and conditions applicable to Open Access Policy Articles, as set forth at http:// nrs.harvard.edu/urn-3:HUL.InstRepos:dash.current.terms-of-use\#OAP

\section{Share Your Story}

The Harvard community has made this article openly available. Please share how this access benefits you. Submit a story.

Accessibility 
H A R V A R D

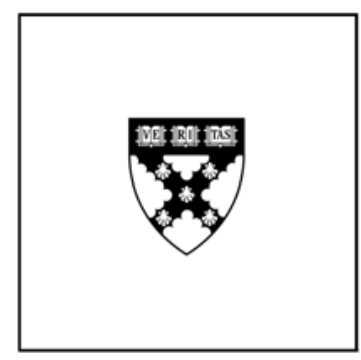

\section{Dodging the Taxman: Firm Misreporting and Limits to Tax Enforcement}

Paul Carrillo

Dina Pomeranz

Monica Singhal

\section{Working Paper}

$15-026$

October 17, 2014 


\title{
Dodging the Taxman \\ Firm Misreporting and Limits to Tax Enforcement*
}

\author{
Paul Carrillo ${ }^{\dagger} \quad$ Dina Pomeranz ${ }^{\ddagger} \quad$ Monica Singhal ${ }^{\S}$
}

October 2014

\begin{abstract}
Reducing tax evasion is a key priority for many governments, particularly in developing countries. A growing literature has argued that the ability to verify taxpayer self-reports against reports from third parties is critical for modern tax enforcement and the growth of state capacity. However, there may be limits to the effectiveness of third-party information if taxpayers can make offsetting adjustments on less verifiable margins. We present a simple framework to demonstrate the conditions under which this will occur and provide strong empirical evidence for such behavior by exploiting a natural experiment in Ecuador. We find that when firms are notified by the tax authority about detected revenue discrepancies on previously filed corporate income tax returns, they increase reported revenues, matching the third-party estimate when provided. Firms also increase reported costs by 96 cents for every dollar of revenue adjustment, resulting in minor increases in total tax collection.
\end{abstract}

JEL codes: $\mathrm{H} 25, \mathrm{H} 26, \mathrm{O} 23, \mathrm{O} 38$

\footnotetext{
*We thank Lorenzo Casaburi, Raj Chetty, John Friedman, Edward Glaeser, James Hines, Lawrence Katz, Asim Khwaja, Henrik Kleven, Michael Koelle, Wojciech Kopczuk, Michael Kremer, Ben Olken, Andrei Shleifer, Joel Slemrod, Johannes Spinnewijn, and participants at the conferences of the American Economic Association, BREAD, Max Planck Institute, National Tax Association, NBER, NEUDC, PACDEV, Swiss Economists Abroad, Tax Systems Conference (Oxford and Michigan OTPR), WADES and in seminars at Brandeis, Columbia, Harvard, Indiana, LSE \& UCL, Lugano, Oxford, PUC Chile, Warwick, Williams and the Centro de Estudios Fiscales for helpful comments and discussions. We thank Sajjad Goli, Andrea Lopez Luzuriaga, Parag Mahajan, Marco Martinez del Angel, and Lucas Zavala for excellent research assistance. We are grateful to the staff of the Centro de Estudios Fiscales and the Departamento de Control of the Ecuadorian Tax Authority for outstanding collaboration and to the Harvard Weatherhead Center, Harvard Taubman Center, and Harvard Business School for research support.

${ }^{\dagger}$ George Washington University, pcarrill@gwu.edu.

${ }^{\ddagger}$ Harvard University and NBER, dpomeranz@hbs.edu.

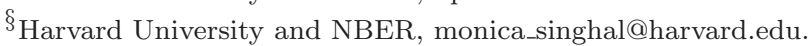




\section{Introduction}

Tax evasion limits the development of fiscal capacity (Besley and Persson, 2013), distorts the allocation of resources in the economy (Skinner and Slemrod, 1985), and can result in a reliance on economically inefficient tax instruments (Gordon and Li, 2009; Best et al., forthcoming). A recent literature has shifted emphasis from the traditional idea of tax enforcement through auditing (Allingham and Sandmo, 1972) toward a focus on "thirdparty information": the ability to verify taxpayer reports against other sources, such as an employer report of salary or the report of a firm's trading partners (e.g., Kopczuk and Slemrod, 2006; Kleven et al., 2010; Pomeranz, 2013). Third-party information is central to modern tax collection in developed countries (Kleven et al., 2009), and the global revolution in information technology has made third-party verification easier than ever before. ${ }^{1}$ Improvements in third-party information would appear to have the potential to transform tax collection, particularly in developing economies.

In this paper, we show a fundamental limit to the effectiveness of third-party information in improving revenue collection: the ability of taxpayers to make offsetting adjustments on less verifiable margins of the tax return. We demonstrate that this behavior can be expected under conditions common in many developing countries, where capacity on other dimensions of the information and enforcement environment are weak. We then provide strong empirical evidence of such adjustments in the context of a natural experiment in Ecuador, in which the tax authority notified firms about discrepancies between their declared revenues and revenue reports from third-party sources. Firms increase reported revenues in response to the notifications but offset almost the entire adjustment with increases in reported costs, resulting in only minor increases in total tax collection.

We begin with a simple conceptual framework to motivate our empirical analysis. In this model, which builds on Kleven et al. (2009), ${ }^{2}$ firms can reduce tax liability by underreporting true profits. If the audit probability is a decreasing function of the reported profit rate, firms will have an incentive to "appear small" by under-reporting revenues and potentially under-reporting costs. Third-party revenue reporting creates a floor on reported revenues but will cause firms to offset some of the resulting higher tax liability by

\footnotetext{
${ }^{1}$ Recent years have seen widespread adoption of electronic tax filing and computerization of tax records (OECD, 2011). Of the World Bank projects with a major tax or customs administration component in the 1990s, over 75\% included computerization of taxes and customs (World Bank, 2012).

${ }^{2}$ NBER Working Paper version.
} 
increasing reported costs. If enforcement capacity on non-third-party reported margins is weak, as is the case in many developing countries, these offsetting adjustments can be large.

We analyze responses to third-party reporting empirically in the context of the corporate income tax in Ecuador. In 2011 and 2012, the tax authority (Servicio de Rentas Internas, SRI) notified a sample of almost 8,000 firms about discrepancies on previously filed corporate income tax returns between their self-reported revenue and information about their revenue from third-party sources. Firms were asked to submit an amended tax return to address the discrepancy. These notifications represent the first time such third-party information was used for tax enforcement in Ecuador in any systematic, large scale way. The discrepancy notifications studied here are representative of how thirdparty reporting is generally used in practice: the tax authority notifies taxpayers about discrepancies and requests that they amend. ${ }^{3}$

We first document widespread misreporting of both revenues and costs relative to third-party information in the cross-sectional universe of all formal firms (60,000 per year). Firms' self-reported revenues are lower than third-party reports in $24 \%$ of firm filings, suggesting substantial scope for improvements in revenue collection through enforcement based on third-party information. We observe little bunching at the third-party amount, consistent with the fact that there was almost no use of third-party reporting by the SRI prior to the notifications. We also find direct evidence that at least some firms under-report their costs. $23 \%$ of all firm filings and $5 \%$ of filings by firms with positive tax liability report costs that are below third-party reported costs. Since third-party reporting of costs is highly incomplete, these estimates provide lower bounds on cost under-reporting. As discussed below, such under-reporting has important implications for tax enforcement more broadly.

We next examine the effect of the discrepancy notifications. Consistent with the idea that lack of credible enforcement capacity can directly limit the effect of information reporting, we find that a substantial share of firms simply fail to file a requested amendment. Our main results focus on firms that do file amended returns, but we still observe strongly statistically significant responses (mechanically attenuated) of both reported revenues and costs in the full sample of all notified firms.

\footnotetext{
${ }^{3}$ Ultimately, expectations about such enforcement will be reflected in taxpayers' original reports; we discuss this further in Section 5.3.
} 
Among amending firms, the discrepancy notifications induce large increases in reported revenues. When firms are given a specific third-party revenue amount by the tax authority, $35 \%$ of all firms that file an amendment revise reported revenues to match the indicated amount exactly. Firms that adjust reported revenues do so by 93 cents on average for every dollar of notified revenue discrepancy. This relationship holds throughout the distribution, including for discrepancies in the hundreds of thousands of dollars. When firms are told that there is a discrepancy but are not provided with a specific amount, revenue adjustments are substantially lower (only 36 cents for every dollar of discrepancy on average). This provides strong evidence that firms are misreporting both before and after the notifications.

However, the effects of these increases in reported revenues on tax payments are severely limited because firms offset the majority of increases in reported revenues with increases in reported costs. For every dollar of revenue adjustment, firms increase reported costs by 96 cents. These effects again hold throughout the distribution. Changes in reported profits were therefore relatively minor, implying that that third-party reporting had little effect on pre-existing levels of evasion (profit under-reporting). Cost offsets are similar regardless of whether or not firms know the exact revenue discrepancy, and we see no correlation between pre-notification reported profit rates and implied profit rates on the amended portion of the return. Taken together, these findings indicate that firms are deliberately targeting their reported cost adjustments to their revenue adjustments. We also see evidence that firms choose cost adjustments on line items that are difficult for the tax authority to verify. For example, the most frequent cost adjustment is to "Other Administrative Costs." As a result of these offsetting cost adjustments, tax collection is an order of magnitude less than it would have been had firms only adjusted revenues.

Our paper contributes to the literature along several dimensions. First, we demonstrate important limits to tax enforcement through third-party reporting, the primary mechanism through which modern governments are able to collect taxes in practice. Third-party reporting has primarily been studied in highly developed countries, in which information reporting is relatively complete and the capacity of the tax authority is high (Slemrod, 2008; Long and Swingden, 1990; Kleven et al., 2010; Gillitzer and Skov, 2013). ${ }^{4}$

\footnotetext{
${ }^{4}$ An exception is Best (2014) who shows that salary reporting by firms limits income tax evasion in Pakistan. See also related work by Kumler et al. (2013) and Naritomi (2013) who examine how changing the incentives of consumers and workers can affect firm compliance and Pomeranz (2013) on how thirdparty reporting may facilitate tax enforcement in the VAT. Sanchez (2014) studies the effects of messages regarding incorrect computations of advance tax payments in the context of Ecuador.
} 
A natural question is whether this form of tax enforcement can be equally effective in developing countries. This is a critical question, since tax evasion is one of the primary challenges faced by developing country governments and recent advances in information technology suggest the potential for dramatic improvements in revenue collection through the use of third-party information.

Since we have data for periods in which third-party information was available but not used by the tax authority for enforcement, we can document and quantify the extent of misreporting by firms as well as directly examine their behavioral responses to the introduction of this form of tax enforcement. We provide clear causal evidence that the benefits of third-party reporting can be undermined when other aspects of the institutional environment are weak, since taxpayers make offsetting adjustments on margins that are difficult to verify. An advantage of our setting is that all notifications refer to previously filed returns, so firms cannot adjust real behavior. We can therefore cleanly isolate the observed responses as pure changes in reporting, something that is typically challenging when examining the effects of tax or other policy changes. Our results show that this method of tax enforcement - on its own - may have limited efficacy in low capacity settings: there are likely to be important complementarities between tax enforcement through third-party reporting and investments in "traditional" auditing and enforcement capabilities. $^{5}$ Our findings - both the observed cross-sectional patterns of misreporting and firm responses to the notifications - can be reconciled in a parsimonious model of firm tax evasion.

Second, our paper contributes more generally to a relatively new empirical literature on public finance in developing economies using administrative tax data (see Besley and Persson, 2013, for a recent review). Our findings are complementary with an emerging set of studies that demonstrate that optimal tax policy may differ across developed and developing countries as a result of differences in information and enforcement constraints (e.g., Gordon and Li, 2009; Best et al., forthcoming). Specifically, these results suggest that governments should set the tax base taking into account the degree of third-party information on the base as a whole. Our results also add to a very limited empirical literature examining the role of technology in improving developing country public sector performance (see, e.g., Lewis-Faupel et al., 2014; Muralidharan et al., 2014).

\footnotetext{
${ }^{5}$ Our framework also predicts such behavior in the small segments of developed country economies that face similar institutional constraints, which is consistent with subsequent findings in Slemrod et al. (2014). See also Klepper and Daniel (1989) who examine cross-sectional patterns of misreporting across types of line items in the United States.
} 
Third, our results relate to the literature on multitasking. In the classic multitasking problem (Holmstrom and Milgrom, 1991), increasing monitoring on one margin will cause agents to adjust not only on the monitored margin but also on other, unmonitored margins. This paper provides the first evidence showing how individual taxpayers adjust their costs when monitoring of their revenues increases. These findings are complementary with Yang (2008), who shows that increased enforcement on one method of customs duty avoidance in the Philippines prompts importers to shift to an alternative duty-avoidance method.

Finally, we are able to study the micro-economics of firm tax misreporting using administrative data. One key novel finding is that some firms under-report their true costs, a result that is consistent with our conceptual framework but runs counter to a natural intuition that evading firms would always inflate their reported costs. ${ }^{6}$ Our framework provides a micro-foundation for the idea that firms may understate overall economic activity to "fly under the radar" of tax or other regulatory authorities (Almunia and Lopez-Rodriguez, 2013). Under-reporting of costs also has important implications. If firms do not have incentives to fully declare costs, the self-enforcement mechanism in the value added tax (VAT) can be undermined (see, e.g., Keen and Smith, 2006). Cost under-reporting could also encourage some firms to remain in the informal sector: formal firms may be willing to trade with informal supplier firms even if these firms cannot provide valid receipts to deduct input costs, a limitation that would otherwise create a disincentive to informality (De Paula and Scheinkman, 2010).

Our results highlight the importance of other aspects of the enforcement environment in determining the effectiveness of third-party reporting. When third-party reporting is highly incomplete and enforcement capacity is weak, as is the case in many developing economies, the effect of third-party reporting on revenue can be dramatically limited as taxpayers respond by adjusting reports on less verifiable margins of the tax return. From a policy perspective, our results indicate that third-party reporting alone is unlikely to provide an easy and immediate solution to the problem of improving fiscal capacity in low-income economies. This does not necessarily mean that countries should not invest in information technologies that support third-party reporting. As we discuss in the concluding section of the paper, third-party reporting could be a powerful tool for tax collection as the scope of transactions covered by third-party reporting expands and the

\footnotetext{
${ }^{6}$ This result is consistent with Kopczuk (2012), who shows that the introduction of a flat tax in Poland lead to increases in both declared revenues and declared costs.
} 
ability to monitor and enforce compliance on non-third-party reported margins increases.

The remainder of the paper proceeds as follows. Section 2 provides a conceptual framework for examining the effects of third-party reporting on firm tax evasion. Section 3 describes the Ecuadorian tax system and outlines our empirical predictions. Section 4 discusses the data and methods. Section 5 presents the results and Section 6 concludes.

\section{Conceptual Framework}

\subsection{Third-Party Reporting in the Allingham-Sandmo Frame- work}

In this section, we develop an illustrative model of the effects of third-party reporting on firm tax evasion to guide our empirical analysis. We begin with a brief review of the standard Allingham and Sandmo (1972) framework and Kleven, Kreiner and Saez (2009) (henceforth KKS), who embed third-party reporting into this framework.

In the Allingham-Sandmo model, which is an application of the Becker (1968) model of crime to the context of tax evasion, taxpayers have true income, $W$, and choose their

level of reported income, $\widehat{W}$. They pay tax on their declared income at rate $\tau$. Evasion is detected with probability $p$, in which case they must pay the owed tax as well as a penalty (at rate $\theta$ ) on the evaded tax (Yitzhaki, 1974). Taxpayers then maximize expected utility, with the first order condition of the following maximization problem implicitly defining $\widehat{W}^{*}$.

$$
E U=(1-p) U(W-\tau \widehat{W})+p U(W-\tau W-\theta \tau(W-\widehat{W}))
$$

A limitation of the Allingham-Sandmo model is that it is difficult to reconcile low observed audit rates and penalties with the generally low levels of tax evasion on many forms of income. KKS (2009) address this concern by allowing $W$ to be comprised of two components: $W_{T}$, which is third-party reported, and $W_{S}$, which is self-reported. Taxpayers choose the reported values of these income components: $\widehat{W_{T}}$ and $\widehat{W_{S}}$. The detection probability on third-party reported income is 1 , so taxpayers will set $\widehat{W_{T}}=W_{T}$. However, in this baseline framework, third-party reporting will be irrelevant to tax collection: taxpayers optimize over total $\widehat{W}$, and $\widehat{W}^{*}$ remains unchanged. Therefore, taxpayers will fully 
offset increases in $\widehat{W_{T}}$ with adjustments to $\widehat{W_{S}}$. Additional constraints - for example, on the detection probability function or on the level or sign of $\widehat{W_{S}}$ - are needed to break this irrelevance result.

\subsection{The Case of Firms}

We now build on this framework to model the effect of third-party reporting on tax evasion in the firm context. Firms have revenues and costs and pay a flat tax on reported profits, defined as reported revenues minus reported costs. Both revenues and costs are potentially comprised of third-party and self-reported components. We will assume throughout that true profit $\pi \geq 0$ and self-reported profit $\widehat{\pi} \geq 0$. We therefore have:

$$
\begin{aligned}
R & =R_{T}+R_{S}=\text { revenues, } \widehat{R}=\text { reported revenues } \\
C & =C_{T}+C_{S}=\text { costs, } \widehat{C}=\text { reported costs } \\
\pi & =R-C=\text { profits, } \widehat{\pi}=\widehat{R}-\widehat{C}=\text { reported profits } \\
\text { Tax } & =\tau \widehat{\pi}
\end{aligned}
$$

Note that there is an important inherent asymmetry in the effect of third-party reporting between revenues and costs. Firms can reduce their tax liability by underreporting revenues and/or over-reporting costs. If third-party reporting is partial, it provides a lower bound on true values. If firms declare $\widehat{R}<R_{T}$, it is clear that they are under-reporting revenues. However, if firms declare $\widehat{C}>C_{T}$, this could be due to over-reporting of costs or due to legitimate costs that were not third-party reported. We return to the implications of this asymmetry below.

\subsection{Firm Responses to Third-Party Reporting}

\subsubsection{General Case}

In a generalized version of the Allingham-Sandmo model, the detection probability is a function of variables observed by the tax authority (firm reports and third-party reports). The penalty conditional on detecting misreporting is a function of the tax rate, firm 
reports, and true revenues and costs. ${ }^{7}$

Firms solve the following maximization problem:

$$
E U=\left(1-p\left(\widehat{R}, \widehat{C}, R_{T}, C_{T}\right)\right) U(\pi-\tau \widehat{\pi})+p\left(\widehat{R}, \widehat{C}, R_{T}, C_{T}\right) U(\pi-\tau \pi-\theta(\tau, \widehat{R}, \widehat{C}, R, C))
$$

We take $R_{T}$ and $C_{T}$ as given for the firm. This assumption is appropriate to our empirical context, in which firms have no opportunity to take actions to change existing third-party reports at the time the notifications are sent.

If revenues and costs enter the detection probability function and the penalty function only in terms of reported profits, $(\widehat{R}-\widehat{C})$, firms can again fully offset all effects of $R_{T}$ by changes to $\widehat{C}$. An increase in $R_{T}$ will cause firms to increase $\widehat{R}$, but they can simultaneously increase $\widehat{C}$, returning to their original optimal level of reported profits with no effect on the detection probability or penalty. In this case, third-party reporting of revenue will have no effect on pre-existing levels of tax evasion, $\tau(\pi-\widehat{\pi})$, or tax collection. Note that, due to the asymmetry reason discussed above, having third-party information on costs does not prevent this full offset. Since third-party reporting creates a floor on reported costs (not a ceiling), firms can increase their reported costs without the tax authority being able to determine whether or not these costs are legitimate. ${ }^{8}$

As we show below, full offsets may not occur if the detection probability or penalty functions treat revenues and costs differentially. Nevertheless, the key result that firms may respond to third-party information by adjusting reporting on margins for which thirdparty information is less binding will continue to hold. This indicates an important link between third-party reporting and traditional auditing, since the effectiveness of thirdparty reporting will ultimately be determined by the tax authority's ability to enforce non-third-party reported margins.

\footnotetext{
${ }^{7}$ We model firms as risk averse. This is a realistic assumption for many developing countries, where a large share of firms are sole proprietorships or owned by a single family and corresponds more generally to a context in which firms dislike volatility on profits. This assumption also allows ease of comparison to the standard Allingham-Sandmo framework. Here, we consider the optimization problem of an individual firm. Please see Pomeranz (2013) for further discussion of cross-firm spillovers in enforcement.

${ }^{8}$ This asymmetry provides a micro-foundation for why costs may be easier to misreport than revenues (Best et al., forthcoming).
} 


\subsubsection{Specifying the Detection Probability}

We now consider a specific case of the detection probability function. We begin with a baseline case in which the tax authority has no third-party information about the firm but can observe whether firms' self-reports seem "internally consistent." The detection probability is therefore a function of firms' self-reported variables $\widehat{R}$ and $\widehat{C}$.

Specifically, we now assume that the tax authority has some information about the true distribution of profit rates. If a firm reports $\$ 100$ in profits on $\$ 1,000$ in revenue, that is more plausible than if the firm reports $\$ 100$ in profits on $\$ 1,000,000$ in revenue. Correspondingly, we assume that the detection probability is $p\left(\frac{\widehat{\pi}+\varepsilon}{\widehat{R}}\right)$ where $p^{\prime}<0$ and $\varepsilon$ is a small number greater than zero. ${ }^{9}$

This specification of the detection probability function is appropriate for our empirical context. In a number of field interviews we conducted, tax authority staff indicated that the reported profit rate is one of the key characteristics they consider when determining whether to audit. Many of the firm owners and tax accountants we interviewed also stated that they pay close attention to the choice of their reported profit rate.

As in Allingham-Sandmo, the penalty is a linear function of the evaded tax. The firm optimization problem is now:

$$
E U=\left(1-p\left(\frac{\widehat{\pi}+\varepsilon}{\widehat{R}}\right)\right) U(\pi-\tau \widehat{\pi})+p\left(\frac{\widehat{\pi}+\varepsilon}{\widehat{R}}\right) U(\pi-\tau \pi-\theta \tau(\pi-\widehat{\pi}))
$$

Proposition 1. Since $p^{\prime}<0$, firms will choose the lowest level of reported revenue consistent with their reported profits. Specifically, as $\varepsilon \rightarrow 0, \widehat{R}^{*}=\widehat{\pi}^{*}$. This then implies that $\widehat{C}^{*}=0$.

Proof. Conditional on $\widehat{\pi}$, the firm prefers to minimize $p$. $\widehat{R} \geq \widehat{\pi}$ and $p^{\prime}<0$ therefore imply $\widehat{R}=\widehat{\pi}$ and $p=p(1)$. Define $\widehat{\pi}^{* *}=\widehat{\pi}^{*}(p(1))$. Now note that the firm can change $\widehat{R}$ while keeping $\widehat{\pi}$ fixed (by adjusting $\widehat{C}$ ), and this does not affect expected utility at a given $p$. This defines $\widehat{R}^{* *}=\widehat{\pi}^{* *}$. The optimal choice of $\widehat{C}$ is then zero.

Intuitively, the firm will maximize its reported profit rate $\frac{\widehat{\pi}}{\widehat{R}}$ in order to minimize its detection probability and chooses the optimal level of reported profits $\widehat{\pi}$ given this

\footnotetext{
${ }^{9}$ The addition of $\varepsilon$ differentiates among corner cases where $\widehat{\pi}=0$, so that declaring zero profits on a large amount of revenue is more likely to trigger additional scrutiny than declaring zero profits on a small amount of revenue.
} 
minimized detection probability. Firms can get to their desired level of profits by adjusting either reported revenues or reported costs, but under-reporting revenues gives the added benefit of reducing the audit rate. They will therefore not even report their legitimate costs. This result arises from the assumption that the tax authority has no information about true revenues and costs (which we relax below) as well as the assumption of a monotonic $p$ function. ${ }^{10}$

The Effect of Third-Party Reporting We now introduce third-party information on revenues. Following KKS (2009), we model third-party reported revenue $\left(R_{T}\right)$ as having a detection probability of 1 .

Proposition 2. Define $\widehat{R}^{*}$ as the optimal firm choice in the absence of third party reporting. If $R_{T} \leq \widehat{R}^{*}$, third-party reporting will have no effect. If $R_{T}>\widehat{R}^{*}$, then $\widehat{R}^{* \prime}=R_{T}$.

Proof. Since $p=1$ if $\widehat{R}<R_{T}, \widehat{R}^{\prime} \geq R_{T}$. Suppose that the firm chooses $\widehat{R}^{\prime}>R_{T}$ implying an optimal level of reported profits $\widehat{\pi}^{* \prime}$, and reported costs $\widehat{C}^{* \prime}$. The firm can now reduce $\widehat{R}^{\prime}$ and increase $\widehat{C}^{\prime}$ by some $\delta>0$. This results in the same level of reported profits but a lower audit probability and therefore higher expected utility. Thus, $\widehat{R}^{* \prime}=R_{T}$

We can now examine the response of $\widehat{\pi}$ to $R_{T}$. Define $Y_{N} \equiv \pi-\tau \widehat{\pi}$ (after tax profits in the non-detected state) and $Y_{A} \equiv \pi-\tau \pi-\theta \tau(\pi-\widehat{\pi})$ (after tax profits in the detected state). Taking the first order condition with respect to $\widehat{\pi}$, we have:

$$
p\left(\frac{\widehat{\pi}+\varepsilon}{R_{T}}\right) U^{\prime}\left(Y_{A}\right) \theta \tau-\left(1-p\left(\frac{\widehat{\pi}+\varepsilon}{R_{T}}\right)\right) U^{\prime}\left(Y_{N}\right) \tau-\frac{1}{R_{T}} p^{\prime}\left(\frac{\widehat{\pi}+\varepsilon}{R_{T}}\right)\left(U\left(Y_{N}\right)-U\left(Y_{A}\right)\right)
$$

The first and second terms capture the standard Allingham-Sandmo trade-off: higher evasion results in higher utility in the non-detected state but lower utility in the detected state. The third term captures the fact that reports by the firm change the detection probability. If $p^{\prime}$ is close to zero, we would expect close to full offsets $\left(\frac{\partial \widehat{\pi}}{\partial R_{T}} \approx 0\right)$. Intuitively, this corresponds to the detection probability function being fairly flat with respect to the reported profit rate. This could be the case, for example, if audit capacity is weak.

\footnotetext{
${ }^{10}$ This assumption could be modified so that a reported profit rate that is "too high" also appears suspicious. Since our main focus is on the effects of third-party reporting, which creates a lower bound on reported revenues, we retain the assumption of a monotonic $p$ function for simplicity.
} 
Cost Under-Reporting One of the implications of our framework is that firms may under-report true costs: in the case above, $\widehat{C}^{* \prime}=R_{T}-\widehat{\pi}^{* \prime}$, but $\widehat{C}^{* \prime} \lessgtr C$. Firms will adjust reported costs in response to an increase in third-party reporting of revenues, but the new level of reported costs may be larger or smaller than true costs. Intuitively, the detection probability function creates incentives for firms to appear smaller on paper than they are in reality by potentially under-reporting both revenues and costs. We present direct empirical evidence in Section 5 that some firms do indeed under-report costs. ${ }^{11}$

\subsubsection{Limits to Enforcement}

Note that the detection probability $p$ is the probability that the firm is caught and punished. We have so far assumed that $p$ equals 1 if firms' self-reported revenues are lower than third-party reports. However, if there are limits to enforcement, $p$ would still rise discontinuously at $R_{T}$ but be limited below 1 . This could occur if the tax authority faces constraints on its ability to enforce tax collection, even conditional on observing misreporting (Aparicio et al., 2011).

In this case, firms may optimally choose reported revenues that are below thirdparty revenues, effectively taking the risk that the tax authority will either not observe the discrepancy or not enforce its elimination. Nevertheless, if $p$ rises discontinuously at $R_{T}$, firms will never choose reported revenues just below this level, instead bunching at $R_{T}$.

We discuss the empirical predictions of the model in more detail in Section 3.3.

\footnotetext{
${ }^{11}$ Somewhat counterintuitively, this suggests that the tax authority could benefit from higher reporting of costs. In particular, if a firm is reporting $\widehat{C}<C_{T}$, forcing it to declare higher costs can result in higher optimal reported profits for the firm for some parameter values.
} 


\section{Background and Empirical Predictions}

\subsection{Firm Taxation and Third-Party Information in Ecuador}

\subsubsection{Rates and Reporting Requirements}

We now turn to our empirical setting: the corporate income tax in Ecuador. Ecuador's per capita GDP in 2011 was approximately 5,000 USD. ${ }^{12}$ Tax revenues are around $12 \%$ of GDP, with indirect taxes comprising about half and corporate income tax making up the majority of the remainder. Oil-related royalties are also an important component of public revenues.

All incorporated firms in Ecuador are required to file an annual corporate tax return (Form F101). Pre-tax profits are defined as the difference between total revenues and total costs. Firms must distribute 15\% of pre-tax profits among their employees and during the years of our study were taxed at a flat rate of $25 \%$ on the remainder. The $25 \%$ rate is independent of firm size and was constant for over 20 years up to and including the years that were affected by the intervention in this study. ${ }^{13}$ There are no tax refunds for losses, but losses can be carried forward, with some limitations, for 5 years with a maximum carry-over deduction amount of $25 \%$ of profits in any given year. The Ecuadorian fiscal year corresponds to the calendar year and firms file the annual corporate tax return the following April.

All firms are also required to file a monthly value added tax (VAT) return (Form F104). In order to deduct input costs, this return must include a purchase annex listing the amount purchased from each supplier along with the supplier's tax ID. A similar annex for sales to client firms must be submitted by firms with annual sales above 200,000 USD as well as by Large Taxpaying Units, public sector firms, financial institutions, credit card companies, and firms requesting refunds of taxes withheld.

\subsubsection{Third-Party Information and Cross Checks}

The Ecuadorian tax authority (SRI) can check firms' self-reports against several sources. For example, it can use data from the purchase annexes to compare a firm's self-reported

\footnotetext{
${ }^{12}$ Ecuador dollarized its economy in 2000. All financial figures in this paper are expressed in USD.

${ }^{13}$ There are certain special provisions that apply to oil companies and public sector companies. These firms are included in our full sample analysis but were not subject to the policy interventions.
} 
sales to the sum of all purchases reported from that firm by other firms. The SRI supplements this information with credit card sales from credit card companies, exports and imports recorded by the Ecuadorian Customs, and returns to financial investments recorded by financial institutions. Since third-party reporting is incomplete, the resulting estimates of firm revenues will generally provide a lower bound on true revenues. ${ }^{14}$

The ability of the SRI to utilize this third-party information is relatively recent. Digitized purchase and sales annex data have only been collected since 2007 and discrepancies were initially computed only in special cases, such as in the process of auditing a large company. The SRI began conducting large scale cross checks of taxpayers in 2011, computing revenue discrepancies for previously filed corporate income tax returns.

\subsection{Policy Intervention}

Our results are based on a series of natural policy experiments in which the SRI notified selected firms about detected discrepancies between firms' self-reported revenues and third-party reported information. Notified firms were asked to file an amended return to address the detected discrepancy. While the specific firm selection methodology is confidential to the SRI, key factors included the magnitude of discrepancies and potential tax adjustments. We discuss firm selection in the context of our empirical strategy in Section 4.2 below.

We examine three rounds of notifications corresponding to tax returns from 2008, 2009, and 2010. We refer to these as the 2008, 2009, and 2010 rounds respectively. The notifications corresponding to the 2008 returns were sent in August-September 2011; the notifications corresponding to the 2009 and 2010 returns were sent in March-April 2012. Note that in all cases, notifications were sent for previously filed tax returns after all real transactions for the relevant tax period had been completed. Therefore, any changes we observe in response to the notifications are reporting rather than real economic responses.

For the 2008 round, 3,136 firms were selected for notification. For the full original notification (in Spanish) see Appendix A2. The relevant portion of the message is translated below:

\footnotetext{
${ }^{14}$ It is possible that there are errors or misreports on the annexes of firms' transacting partners, but given the incompleteness of third-party information, the resulting estimates of $R_{T}$ will still be underestimates of true revenues in most cases.
} 
"Dear Mr/Mrs [XXX], General Manager of Firm [XXX],

After reviewing the databases which it possesses, the Tax Administration has identified revenue amounts that are attributable to the firm that you represent, which are larger than the amount reported on its 2008 corporate income tax return. [...] The Tax Administration requests that you submit an amended return for the year 2008 via internet within 10 business days."

2,221 firms were selected for the 2009 round and 2,636 firms for the 2010 round. In these rounds, the notifications also included the SRI's calculation of firm revenue based on third-party sources (Appendix A3). The relevant portion of the message is translated below:

"Dear Mr/Mrs [XXX], General Manager of Firm [XXX],

After reviewing the databases which it possesses, the Tax Administration has identified revenue amounts that are attributable to the firm that you represent, which are larger than the amount reported on its $20 X X$ corporate income tax return, as shown in the following table:

\begin{tabular}{|c|c|c|c|}
\hline Fiscal Year & $\begin{array}{c}\text { Line Item of the } \\
\text { Corporate Income Tax }\end{array}$ & $\begin{array}{c}\text { Value Calculated by } \\
\text { the Tax Administration }\end{array}$ & $\begin{array}{c}\text { Value Declared } \\
\text { by the Taxpayer }\end{array}$ \\
\hline 20XX & 699. Total Revenue & $\$ 255,300$ & $\$ 190,500$ \\
\hline
\end{tabular}

[...] The Tax Administration urges you to submit an amended return for the year 20XX via internet."

Notifications were sent by email to the address on record, which typically belongs to the general manager or accountant of the firm. We observe firms' initial filings as well as any subsequent amendments made to their returns.

\subsection{Empirical Predictions}

We can think of the discrepancy notifications as effectively introducing $R_{T}$ for notified firms. Recall that the key effect of third-party reporting is to create a threshold for reported revenues below which there is a discontinuous increase in the probability that misreporting is detected and penalized. Prior to the notifications, third-party information was not used for enforcement purposes, except for selected audit cases. The detection probability function faced by firms was thus equivalent to one in which the tax authority 
had no third-party reports $\left(R_{T}=0\right)$.

In the full cross-section of firms, the absence of enforcement based on $R_{T}$ implies that we should see little to no bunching at $R_{T}$ but we may have optimal reported revenues both below the third-party level and above. The framework also predicts that some firms may under-report costs, setting $\widehat{C}<C$. While we do not observe real costs $C$, we can perform a stricter test for cost under-reporting by examining whether firms report $\widehat{C}<C_{T}$. $C_{T}$ is likely to be substantially smaller than $C$, since only a small share of firms are required to file sales annexes. This test will therefore provide a lower bound on the extent of cost under-reporting. ${ }^{15}$

We next turn to the predictions for the discrepancy notifications. All firms in the policy intervention have $\widehat{R}<R_{T}$ by definition, since the SRI sent notifications only to firms that under-reported revenues relative to available third-party information. Our context best corresponds to the "limits to enforcement" case in Section 2.3.3: firms could only have been legally prosecuted for failure to submit an amended return if a written notification had been delivered to them in person by a member of the SRI staff. This is very expensive, and the email option for notifications was chosen due to resource constraints. If there are limits to enforcement, some firms may simply choose not to file an amendment.

Finally, among firms that do file an amendment, we should see bunching of reported revenues at $R_{T}$ when $R_{T}$ is disclosed, i.e., in the 2009 and 2010 rounds. In the 2008 round, in which $R_{T}$ was not disclosed to firms, amended reported revenues may be above or below the actual $R_{T}$. In all rounds, we expect to see firms offsetting the increase in reported revenue with an increase in reported costs. The magnitude of this effect will depend on the gradient of the audit probability with respect to the reported profit rate: large offsets would imply a relatively flat gradient.

\footnotetext{
${ }^{15}$ It is possible that supplier firms misreport sales, on which the third-party cost variable is based. However, since the incentive is for firms to under-report revenues, this will typically result in a lower $C_{T}$.
} 


\section{Data and Empirical Strategy}

\subsection{Data}

We combine several sources of administrative data. Information about self-reported revenues and costs on original and amended tax returns is compiled from the corporate income tax form F101. We observe values for all line items as well as the submission date for each amended version of the return. Firms can submit amendments to the F101 without presenting any additional documentation.

Revenue and cost discrepancies are calculated using third-party data. Specifically, third-party reported revenue is the sum of exports, bank interest, and the maximum of the sum of purchases from the firm reported by client firms and the sum of purchases from the firm made using credit cards. Third-party reported costs are the sum of firms' imports and sales reported by their suppliers. Purchases and sales reported by supplier and client firms are calculated by the SRI using data from the F104 annexes described in Section 3.

The third-party revenue measure was hand checked by SRI staff for the sample of notified firms, resulting in some adjustments. These adjusted measures of $R_{T}$ were provided to firms in the 2009 and 2010 rounds and were calculated (but not provided to firms) in the 2008 round. We use the adjusted third-party measure for evaluating responses to the discrepancy notifications and the unadjusted measure for cross-sectional results. In practice, the adjusted and unadjusted measures are highly correlated, and the policy experiment results are robust to excluding firms for which adjustments were made.

We define the universe of economically active firms in a given year as those which filed an F101 and had non-zero revenues or costs, based on self-reported or third-party reported information. In 2008, we do not have third-party reported information for firms outside the notification sample and therefore restrict the sample to firms with non-zero costs or revenues based on self-reported information for this year. ${ }^{16}$

Table 1 shows summary statistics for the full universe of economically active firms for fiscal years 2008-2010 (pooled). The sample includes 87,076 firms and almost 200,000 firm-year observations. The mean declared annual revenue is $\$ 1.58$ million with a median

\footnotetext{
${ }^{16} 23 \%$ of firms in the 2009-10 sample had zero costs and revenues based on self-reports but positive values based on third-party reports.
} 
of $\$ 42,200$. Declared costs have a mean of $\$ 1.48$ million and a median of $\$ 41,600$. Correspondingly, there is a large range in tax liabilities. The mean is $\$ 23,000$, the median is zero, and the standard deviation is over $\$ 600,000 .{ }^{17}$ Firms' self-reported revenues and costs are higher than third-party reports on average. Note that since third-party information is incomplete, this does not necessarily mean that firms are over-reporting these values. In addition, as we discuss in detail below, a substantial share of firms report lower revenues or costs than the third-party reports.

Table 2 Panel A shows summary statistics for the firms that were selected for notification in each round of the policy intervention (henceforth referred to as the "notification sample"). All numbers reflect the last pre-notification filing for the corresponding tax year. For all firms selected for notification, self-reported revenues are lower than thirdparty reported revenues. Revenue discrepancies are large, both in absolute terms and as a share of baseline self-reported revenue. The mean discrepancy is $\$ 307,000, \$ 176,000$ and $\$ 197,000$ in 2008, 2009 and 2010 respectively. ${ }^{18}$ To analyze the relative size of the discrepancy, we examine the distribution of $\left(R_{T}-\widehat{R}\right) /(\widehat{R}+1)$. The median is 0.63 .

There were 3,136 firms selected for the 2008 round, 2,221 for the 2009 round, and 2,636 for the 2010 round. Some firms were notified in more than one round. Our results are robust to restricting the sample to firms that were only notified once, and all standard errors are clustered at the firm level. Not all firms selected for notification actually received them: approximately $7 \%$ of messages bounced due to invalid email addresses, and it is quite likely that additional notifications were not received or read by the intended recipients: email addresses may have been out of date or belonged to accountants or other individuals that no longer work for the firm. We can therefore think of the notification sample as an intent-to-treat sample.

Panel B of Table 2 presents summary statistics for firms that submitted an amended return after receiving the notification (henceforth referred to as the "amending sample"). We count a firm as amending if it filed an amendment within three months after the notification. ${ }^{19}$ The share of amending firms in the notification sample was $19 \%$ in the

\footnotetext{
${ }^{17}$ The fact that the median firm reports zero tax liability is not unique to Ecuador. In the US, for example, an average of $65 \%$ of firms reported no tax liability (U.S. Government Accountability Office, 2008). This figure reflects US held corporations that filed the 1120 or $1120 \mathrm{~A}$ tax form between 1998 and 2005.

${ }^{18}$ Conversations with SRI staff confirm that summary statistics for the 2008 round differ from the 2009 and 2010 rounds because the selection criteria for receiving a notification were changed somewhat for the later years; summary statistics for the full sample are very similar across the three years.

${ }^{19}$ In 2009 and 2010, we observe the firm-specific notification date. In 2008, as we discuss in Section 4.2,
} 
2008 round, $11 \%$ in the 2009 round, and 16\% in the 2010 round. Note that these figures understate true response rates since, not all firms in the notification sample actually received the notification. We cannot determine the share of firms that received and read the notification and made an active decision not to amend. Nevertheless, the observation that a substantial share of firms chose not to amend is consistent with the case of limits to enforcement discussed above. If the probability that a firm is detected and punished is bounded below one, even conditional on a discrepancy, some firms may rationally choose not to amend, taking the chance that the tax authority lacks the enforcement capacity to follow up and force them to rectify the discrepancy. This is plausible in the Ecuadorian context. Amending firms are somewhat smaller in terms of overall self-reported economic activity than the full notification sample, but median revenue discrepancies are quite similar.

Given the magnitude of revenue discrepancies, notifications had the potential for large effects on total tax collection. For example, if all firms in the 2009 and 2010 rounds had amended their returns to match the indicated third-party reported amount, aggregate pre-tax revenue would have increased by approximately $\$ 391$ and $\$ 522$ million for the 2009 and 2010 fiscal years, respectively. If other line items were held constant, this would imply a total increase in tax collection of approximately $\$ 194$ million. ${ }^{20}$ Among just the amending firms, implied increases in total tax collection are $\$ 39$ million and $\$ 76$ million for 2009 and 2010 respectively. As we show below, actual tax revenue increases were substantially smaller because firms offset their revenue adjustments with adjustments to reported costs.

\subsection{Empirical Strategy}

We are able to estimate the causal effects of the notifications without an explicit control group by comparing firms' post-notification and pre-notification returns. The underlying identifying assumption is that in the absence of the notification, firms would not have amended their returns. In this case, firms' own pre-notification reported values provide a

we impute the exact notification start date. We assume that the 2008 notifications were made over a one-month period following the start date, as in 2009 and 2010, and therefore consider amendments filed within a four-month window of the start date in 2008 to be as consistent as possible with the later rounds. In practice, over half the firms that amended their return responded in less than one month and our results are robust to choice of the post-notification window.

${ }^{20}$ This is calculated as the tax rate $(25 \%)$ multiplied by $85 \%$ of the additional declared revenue, since $15 \%$ of profits are meant to be distributed to workers. 
valid counterfactual for post-notification reports.

Indeed, the probability that firms spontaneously revise their returns for previous years after such a long period absent a notification is very low. Figure 1 plots amendment rates for the notification sample (right hand column) and for the rest of the full sample (left hand column). The start of the notification period is indicated by zero on the xaxis. Amendment rates are very close to zero for both samples prior to the notifications. There is a stark increase in the amendment rate for the notified sample following the start date, but no such increase in the non-notified sample. Moreover, as we show below, the types of adjustments made by non-notified firms that happen to revise their returns are entirely different from the amendments by notified firms. Correspondingly, the comparison between the pre-notification and post-notification returns provides a causal estimate of the discrepancy notification on firms' reporting behavior.

In the 2008 round, we know that notifications were sent in August and September of 2011 but we do not observe the firm-specific notification dates. Based on the timing of the discontinuity in the amendment rate, we impute the start date for the 2008 round as August 11, 2011. In the subsequent analysis, we use the firm-specific notification dates for the 2009 and 2010 rounds and August 11, 2011 as the notification date for the 2008 round. The pre-notification reports are defined by the last F101 filing or amendment prior to these dates. The post-notification reports are defined by the first observed amendment (if any) after the notification during the post-notification windows defined in the preceding section.

Firms were selected for notification based in large part on their revenue discrepancies and potential tax adjustment. The sample of firms selected for notifications is of course not representative of the population of all firms in Ecuador. However, it is of particular interest in the context of tax enforcement, since firms with large discrepancies are the ones with the greatest potential for improved tax collection through third-party based enforcement. Therefore, such enforcement strategies typically target this type of firm.

\section{Results}

Section 5.1 examines the pattern of revenue and cost discrepancies in the full sample in 2009 and 2010, the two years for which we have data on third-party reported revenues and costs for all firms. Section 5.2 analyzes the impacts of the discrepancy notifications. 


\subsection{Evidence from the Full Sample of Firms}

\subsubsection{Revenue Discrepancies}

Figure 2, Panel A plots the difference between the log of self-reported revenue and the $\log$ of third-party reported revenue for firms with non-zero third-party reported revenue. We add 1 in all log specifications to deal with zero self-reports.

As seen in Table 1, self-reported revenues are on average larger than third-party reported revenues. At the same time, we also see $24 \%$ of filings with reported revenues below third-party revenues. We observe a small degree of bunching around $R_{T}$. However, this bunching is not sharp: only $3.8 \%$ of filings have self-reported revenues that exactly match the third-party estimate, and these are cases where $R_{T}$ is relatively small on average. As we will show, responses to the notifications result in bunching that is an order of magnitude larger.

\subsubsection{Cost Discrepancies}

Figure 2, Panel B plots analogous differences in costs for firms with non-zero third-party reported costs. We observe firms with declared costs both above and below the third-party level and essentially no bunching at $C_{T} \cdot{ }^{21}$

One of the predictions of our model is that firms may under-report costs, counter to the intuition that firms should wish to over-report costs in order to reduce tax liability. We can look at this issue by analyzing whether firms report costs below the third-party reported costs $\left(\widehat{C}<C_{T}\right)$. This will provide a lower bound on the extent of true cost underreporting $(\widehat{C}<C)$ because third-party reporting for costs are even more incomplete than third-party reporting for revenue. We find that indeed, $23 \%$ of returns report costs that are lower than third-party reported costs. Firms that declare zero tax liability may have limited incentives to declare all costs, even though some degree of loss carryover is allowed. However, we find that firms under-report costs even when declaring positive tax liability: $9 \%$ of returns that under-report costs have positive tax liability and $5 \%$ of all returns that have positive tax liability exhibit cost under-reporting.

The finding that firms under-report costs not only provides empirical support for our

\footnotetext{
${ }^{21}$ If we examine the full sample, including filings for which we do not have third-party information, we see somewhat stronger bunching at both $R_{T}$ and $C_{T}$ (Appendix Figure A1). This additional bunching reflects cases in which both the self-report and the third-party report are zero.
} 
conceptual framework but also has broader implications, for example for the effectiveness of the VAT. A key benefit of the VAT is that it has self-enforcing properties as a result of the conflicting incentives between buyers and sellers. Specifically, although sellers have incentives to under-report the value of the transaction, buyers will want the transaction to be reported fully in order to maximize their cost deductions. If, however, buyers are not reporting all input costs, this self-enforcement mechanism can be undermined.

\subsection{Response to Notifications}

This section analyzes the responses to the discrepancy notifications. We examine how firms adjust their reported revenues in response to the notifications and then consider effects on reported costs and overall tax liabilities. Our main specifications focus on the sample of amending firms. We also present results for the full notification sample. These results are mechanically attenuated, since a firm in the notification sample that did not file an amendment will have no change to its reported revenues and costs by definition, but the estimates are still highly statistically significant.

\subsubsection{Revenue Adjustments}

As expected, we see strong bunching at the third-party revenue amount $\left(R_{T}\right)$ in response to the notifications when firms are provided with a specific value for $R_{T}$ (2009 and 2010 rounds). The first two graphs of Figure 3 show the difference between the log of post-amendment self-reported revenue and the log of third-party reported revenue among amending firms for the 2009 and 2010 rounds. There is very large bunching around zero, indicating that firms are adjusting their revenues to match the provided estimate of $R_{T}$. Thirty-nine percent of firms in the 2009 round and 35\% of firms in the 2010 round match exactly, setting $\widehat{R}^{\prime}=R_{T}$. This contrasts notably with the full sample results (Figure 2) in which we see minimal sharp bunching (3.8\%).

Figure 4 shows these revenue responses in more detail, plotting the change in reported revenue (revenue adjustment) against the pre-treatment revenue discrepancy. Panel A shows results for amending firms. Approximately 15\% of amending firms filed an amendment but did not change reported revenues or any other major variables. These firms are essentially analogous to non-amending firms. We therefore define the sample of adjusting firms as firms which made any positive adjustment to revenue following the notifications 
(Panel B).

The first two graphs of Figure 4, Panel B present the results for adjusting firms for the 2009 and 2010 rounds. Firms tend to locate closely along the 45-degree line, matching the third-party estimate. This shows that the observed bunching around zero in Figure 3 is not limited to small firms: even firms with very large revenue discrepancies match the third-party amount in their amended returns. ${ }^{22}$ To the extent that there is incompleteness or noise in the SRI's measure of $R_{T}$, these results indicate that firms match the estimate provided to them.

Next, we can test whether the bunching is a direct result of the information provided in the notifications by comparing these findings to the 2008 round. For 2008, firms were only told that their reported revenues were below third-party reported amounts but were not given an actual value of $R_{T}$. As expected, we observe much less bunching, and only $6 \%$ of firms match $R_{T}$ exactly (Figure 3 ). This exact matching in the 2008 round could reflect some firms seeking out and obtaining additional information about their revenue discrepancies from the SRI. Firms with larger revenue discrepancies make larger revenue adjustments on average, but there is much higher variance than in the 2009 and 2010 rounds (Figure 4). In addition, the fitted line in Panel B lies clearly below the 45-degree line: firms in the 2008 round adjust revenues by only 36 cents for every dollar of actual revenue discrepancy estimated by the SRI.

Comparing the 2008 round with the 2009 and 2010 rounds yields several implications. First, it is clear that firms are adjusting their revenues specifically in response to the information provided in the notifications rather than just the receipt of a notification from the tax authority itself. Second, the results provide strong evidence of misreporting both before and after the notifications. The 2008 adjustments indicate that firms have substantial scope for upward revision in reported revenues. Since $R_{T}$ is a lower bound on true revenues, this indicates that firms in all rounds are likely to be under-reporting revenues even in the post-notification filings. Finally, the fact that firms make smaller adjustments when not provided the specific amount of $R_{T}$ is consistent with the idea that firms will optimally try to minimize reported revenues $(\widehat{R})$ and also suggests that they are underestimating the ability of the tax authority to collect third-party information.

The results are not consistent with an alternative in which the notifications simply

\footnotetext{
${ }^{22}$ The displayed data points are restricted to the range zero to one million, but the fitted line and confidence interval reflect the unrestricted sample.
} 
prompt firms to review their books and correct inadvertent omissions in reported revenues: $28 \%$ of firms in the notification sample and $38 \%$ of the adjusting sample reported zero revenues on their initial returns. In Ecuador, as in some other countries, there are strong incentives for registered firms to continue to file annual returns even if they truly had no economic activity in a given year. ${ }^{23}$ Therefore, the filing of a return with zero reports does not raise a red flag for the tax authority in and of itself. Since it is unlikely for firms to "forget" that they had any economic activity, lazy reporting on initial filings alone cannot explain the observed patterns of under-reporting and adjustment.

Figures 3 and 4 display revenue discrepancies and adjustments in absolute terms without making adjustments for firm size. Appendix Figure A2 shows results that adjust for firm size by scaling both axes by baseline reported revenue. If anything, observed matching is stronger.

Table 3 presents the results in regression form along with robustness tests. Panel A shows the response in reported revenue in the pooled 2009 and 2010 rounds. Standard errors are clustered by firm, and all results are statistically significant at the $1 \%$ level. The baseline regression coefficient corresponds to the fitted line in Figure 4, Panel B. This coefficient is 0.927 , indicating that adjusting firms increase their reported revenues by 93 cents for every dollar of indicated third-party revenue.

This estimate is robust to a variety of specification adjustments. Restricting the sample to firms notified in only one round, the coefficient is 1.016. The effects are not driven by firms responding to large revenue discrepancies: the coefficients are almost identical when we restrict the sample to firms with revenue discrepancies below $\$ 1,000,000$ or below $\$ 250,000$, confirming that the observed effects hold throughout the distribution. A very small number of firms make negative revenue adjustments; including these firms has a negligible effect on the estimated coefficient (0.926). Our baseline specification uses the last F101 filing prior to the notifications as our baseline measure of reported revenue. In some cases, the measure of baseline revenue provided to firms on the letters from the SRI differs slightly. Using the letter measure in our calculation of revenue adjustments again makes little difference to the results (0.932). Finally, as mentioned above, the measure of $R_{T}$ provided to firms is derived from the third-party reported data but was hand checked by SRI staff and adjusted in some cases. Our results are robust to excluding cases where such adjustments were made (1.111).

\footnotetext{
${ }^{23}$ Inactive firms face fines if they fail to submit tax returns until the firm is legally closed, a process which is costly and can take several years.
} 


\subsubsection{Cost Adjustments}

We now demonstrate that firms make substantial offsetting adjustments to these changes in reported revenues by changing reported costs. Figure 5 plots the change in reported costs against the change in reported revenue for adjusting firms. In all three rounds, firms locate almost exactly along the 45-degree line, indicating that they closely match increases in reported revenues with increases in reported costs. This behavior holds along the entire distribution of changes in reported revenue, even when revenue adjustments are in the hundreds of thousands of dollars. Over $15 \%$ of firms match their cost adjustments to their revenue adjustments within $\$ 100$, with about half of these matching exactly. Almost $30 \%$ of firms match within $\$ 1,000$. The median revenue discrepancy in the notification sample is $\$ 50,000$.

Although we observe differences in revenue adjustments depending on whether or not firms are provided a specific value of $R_{T}$, cost adjustments match revenue adjustments closely in all three rounds. This indicates that firms are choosing their level of reported costs in a way that targets their optimized levels of reported revenues. Table 3 Panel B presents corresponding regression analyses for the pooled 2008-2010 rounds. The baseline regression coefficient corresponds to the fitted line in Figure 5. This coefficient is 0.962, indicating that adjusting firms increase their reported costs by 96 cents on average for every dollar of revenue adjustment. This result is stable across all of the same robustness checks as in Panel A, described in Section 5.2.1, and robust to scaling adjustments by baseline reported revenues (see Appendix Figure A3).

These findings imply that the use of third-party information had little effect on tax evasion (the gap between true and reported profits). A natural question is why the tax authority would not immediately pursue these firms. While we do not have information on actions taken against specific firms, conversations with SRI staff indicate that they are indeed in the process of follow-up control efforts. However, such efforts suffer from the exact problem third-party cross-checks are meant to mitigate. Following up with firms would require in-person audits, which are time consuming and very costly. The main advantage of third-party reporting is that, unlike audits, it is meant to provide a simple, low-cost mechanism to enforce tax collection. The central challenge when thirdparty reporting of costs is partial is that the tax authority cannot definitively distinguish between legitimate additional reported costs and false costs without a full audit. This inability to differentiate real from fake costs using firm reports alone is in fact what allows 
firms flexibility in adjusting their costs and puts limits on the power of enforcement based solely on information from third-party reporting of revenue.

While our results on cost under-reporting suggest that there is some scope for new reporting of legitimate costs, we also find suggestive evidence that firms are including fake costs in their amendments. In particular, firms disproportionately choose cost adjustments on line items that would be difficult for the tax authority to verify in the event of a full audit. Ecuadorian firms are required to distinguish between production costs ("costos") and administrative costs ("gastos"), with many cost line items including both a "costo" and "gasto" component. As confirmed by Ecuadorian tax officials, the provision and value of many administrative costs, such as legal or consulting services, are more difficult to verify than physical inputs to production.

Within each line item category, adjustments to gastos are more frequent than adjustments to costos. The most frequent cost adjustment is on "Other Administrative Costs," a line item that is particularly hard to verify because it may contain miscellaneous purchases including transactions with the informal sector. Fifty percent of adjusting firms report zero "Other Administrative Costs" before the amendment, while only 25 percent report zero after the amendment. We find that the ratio of total gastos (summed across adjusting firms) to total costs is higher on the amendments than on pre-notification returns, and the ratio of "Other Administrative Costs" is $6.5 \%$ on the amended portion of the return, compared to $3.8 \%$ on the initial filings. Taken together, these results suggest that firms are systematically increasing reported costs on line items that are difficult for the tax authority to verify relative to their pre-notification returns.

To the extent that some additional costs are legitimate, firms could potentially be responding to the notifications by bringing entire transactions (revenues together with their associated costs) on the books (Kopczuk, 2012). We next look at whether such behavior could fully explain the adjustments we observe in the data. As seen above, many firms match their cost adjustments extremely closely to their revenue adjustments. For example, over $15 \%$ of adjusting firms match their cost adjustments to their revenue adjustments within $\$ 100$, which would only be consistent with bringing zero profit transactions on the books. In addition, if firms were responding to the notifications only by bringing entire transactions on the books, we would expect to see a positive correlation between firms' reported profit rates prior to the notifications and the reported profit rate on the amended portion of the return. We find no such correlation: among all adjusting firms, the correlation coefficient between the pre-notification profit rate and profit rate on 
the amendment is -0.01. Among adjusters with positive pre-notification reported profits, the correlation is actually negative. This indicates that firms seem to be choosing new optimal levels of reported costs based on their new levels of reported revenue.

\subsubsection{Effects on Tax Revenue}

Given the results above, it is not surprising that overall effects on tax collection are modest. Figure 6 plots a histogram of changes in the log of tax liability for adjusting firms. We see a large spike around zero, consistent with firms having offset much of their revenue adjustments with corresponding cost adjustments.

Table 4 presents regressions of revenue adjustments, cost adjustments, and resulting changes in tax liability on our indicator for post-notification for the amending sample (Panel A) and the full notification sample (Panel B). The coefficient on 'post' indicates the difference in declared amounts before and after the notifications. If a firm made no amendment in the relevant post-notification window, its post-notification values are the same as its pre-notification values. Standard errors are clustered at the firm level, and all results are significant at the $1 \%$ level.

Panel A shows that amending firms on average increased their reported revenues by $\$ 86,000$ and costs by $\$ 80,000$, resulting in an average increase in tax liability of $\$ 1,900$. This increase in tax liability is an order of magnitude smaller than it would have been had firms adjusted only revenues. We see similar patterns in the full notification sample (Panel B). These effects are mechanically attenuated by the amendment rate, since non-amender firms had zero adjustments by definition. However, even in this sample, the observed effects are significant at the $1 \%$ level. Our estimates imply that the total incremental tax collection attributable to the notifications was approximately $\$ 2$ million.

Finally, we return to our initial identifying assumption, which is that the pre-post difference in firms' reports can be taken as a causal effect of the notifications. Table 5 shows a placebo test in which we simulate treatment effects for non-notified firms, assuming that these firms had been notified on the first day of the notification period in each year. Panel A includes all non-notified firms and Panel B includes non-notified firms that happened to make an amendment during the relevant period. There are no significant changes in revenues, costs, or tax liabilities, and the point estimates for revenue and cost adjustments are of opposite sign. This provides strong support for our identifying assumption. 
Overall, our results provide strong evidence indicating the limits of third-party reporting. While the notifications did cause firms to adjust their reported revenues to match third-party reported amounts, firms offset much of this adjustment by increases in reported costs. These results cannot be driven by real economic responses, since all transactions for the relevant tax returns were made well prior to the notifications. The pattern of responses provides strong evidence of misreporting by firms, both before and after the notifications.

Our empirical findings - both the observed cross-sectional patterns and the responses to the notifications - can be reconciled in our conceptual framework. ${ }^{24}$ Independently of the underlying model, our results have important implications, which we believe are broadly generalizable to many low income countries. First, there is substantial misreporting of both firm revenues and costs, and evading firms may under-report true costs in addition to revenues. Second, the effectiveness of third-party reporting depends on other features of the enforcement environment. The notifications studied here are precisely the type of policy any government would pursue in order to utilize third-party information for enforcement: cross-check taxpayer reports, detect discrepancies, and request taxpayers to revise their filings accordingly. However, the effect of such policies on revenue collection may be constrained by other aspects of tax administration, such as low detection capacity or low enforcement capacity conditional on detection. These limitations could result from limited governmental resources, corruption, or weak legal environments, common concerns in many developing economies.

\subsection{Taxpayer Reports in Subsequent Tax Filings}

The above analyses examine how firms respond to ex post notifications of detected discrepancies. As taxpayers update their beliefs about the information available to the tax authority, we would expect them to adjust their ex ante behavior for subsequent tax years. Most individuals in the United States, for example, report their W2 income accurately because they know that discrepancies will be detected and prosecuted with near certainty.

In our context, we might expect notified firms to report both higher revenues and costs on post-notification returns. An empirical challenge is constructing an appropri-

\footnotetext{
${ }^{24}$ In the context of the model, the large cost offsets we observe are consistent with a low gradient of the detection probability with respect to the reported profit rate. The failure of some firms to amend in response to the notifications reflects the fact that the effective detection probability (the probability that the firm is both caught and punished) is less than one, even conditional on a revenue discrepancy.
} 
ate counterfactual for notified firms' subsequent returns. Defining a control group using propensity score matching is not suitable for this context: in cases in which firms with large revenue discrepancies were excluded from being notified, this generally occurred for a specific reason, such as an existing ongoing investigation by the SRI. We therefore do not have an ideal control group for notified firms.

The best we can do to shed some light on this question is to exploit a source of variation from the design of the 2008 notifications. The SRI had initially selected a larger group of firms for notification, but some firms in this sample were not notified due to technology resource constraints. We can thus use the selected-but-not-notified firms as a control group for notified firms. This control group is imperfect: the SRI staff used discretion in prioritizing firms for notification within the selected sample. We therefore stress that these results can provide only suggestive evidence about subsequent responses.

The 2008 notifications were sent in the summer of 2011 and could potentially influence both firms' economic decisions in the latter portion of the year and reporting choices in their 2011 tax return (due in April 2012). Hence, subsequent responses to the 2008 notifications will be captured by differences in the 2011 tax returns between treatment and control groups. We restrict the sample to firms that were selected for notification for the 2008 round only, resulting in 2,046 and 1,035 firms in treatment and control groups, respectively.

Appendix Figures A4 and A5 plot mean revenues and costs for treatment and control groups for the 2008-2011 tax years. We see quite large differences in levels but pre-trends are broadly similar. We observe a divergence in the 2011 tax year, with the treatment group reporting both higher revenues and higher costs than the control group. However, there are some increases, though smaller, in the 2010 tax year as well. Appendix Table A1 shows regressions of revenues, costs, and tax liability on an indicator for 2011 interacted with an indicator for treatment with firm fixed effects. The treatment group indeed has significantly higher reported revenues and costs than the control group. A placebo test using reports for the 2010 tax year results in insignificant results; the point estimates are approximately one-third the size of the 2011 effects (unreported).

These results provide some suggestive evidence that firms do in fact adjust their behavior subsequent to the notifications as we would expect. However, given the nature of the source of variation, we cannot rule out the possibility of different underlying trends between treatment and control groups. Gaining a better understanding of how taxpayers 
respond to updated perceptions about the information and enforcement capacity of the tax authority would be an interesting avenue for future research.

\section{Conclusion}

This paper investigates the impact and potential limitations of tax enforcement based on third-party information. When firms are notified by the tax authority about detected revenue discrepancies, they amend their returns and increase reported revenues, closely matching the amount indicated when it is provided. However, they offset much of this higher declared revenue by an increase in declared costs, resulting in only small changes in their reported profits, implied tax evasion, and corresponding corporate tax liabilities. This is true even when adjustments are in the tens or hundreds of thousands of dollars. This highlights the importance of taking possible offsetting adjustments into account when examining the effectiveness of tax enforcement measures. We also document substantial misreporting in the universe of firms in Ecuador, using third-party information on revenues and costs. Notably, we find evidence that some firms under-report not only revenues but also costs, even when they have positive tax liability. These empirical findings can be reconciled in a simple model of third-party reporting in which the detection probability depends on the firm's reported profit rate.

Our results have a number of implications for tax enforcement and public finance in developing countries. First, these results indicate limits to the power of enforcement policies based on third-party information when such information is partial. In particular, the collection of third-party information may have different levels of effectiveness depending on the amount of information available on other margins: as in the O-ring theory of economic development (Kremer, 1993), the weakest link may play a preponderant role for tax collection. Third-party reporting is therefore likely to be most effective when there are relatively few margins that are not third-party reported and when the tax authority can audit these margins effectively. In many developing countries, however, third-party reporting is highly incomplete and there are severe limits to the effectiveness of traditional auditing. In these types of environments, third-party reporting may not be a silver bullet in solving the problem of improving state fiscal capacity.

Second, the fact that some firms appear to under-report their costs in addition to under-reporting revenues has several important implications. Cost under-reporting can 
undermine certain types of compliance incentives. For example, one of the main attractive features of the VAT is that it has self-enforcing properties if buyers want to fully declare costs to maximize their input deductions. However, if buyers have incentives to underreport true costs, opportunities for evasion and collusion in the VAT can arise. In addition, one of the costs of informality - limited ability to trade with the formal sector - may be reduced. When firms want to report all their input costs, they may avoid informal suppliers who cannot provide a receipt (De Paula and Scheinkman, 2010). If firms are not fully maximizing their reported costs, this barrier is diminished.

Since cost under-reporting can undermine certain forms of cross-firm compliance incentives, enforcement that increases cost reporting can lead to positive spillovers. ${ }^{25}$ If firms were required to accompany additional cost deductions with information about the providers of these input costs, enforcement based on third-party reported information can in turn generate more such information. Gaining a better understanding of the extent of such spillover effects is an important avenue for future research.

Third, our findings suggest ways in which governments should take limits to information and enforcement capacity into account when designing tax policy. In particular, the optimal tax base will depend on the degree of available third-party information on the base as a whole. For example, if firms are able to offset reported revenues with reported costs, it may be optimal to limit allowable cost deductions to those that are easy to verify. Our empirical findings are complementary with Best et al. (forthcoming), who show that governments may prefer productively-inefficient turnover taxes to profit taxes when costs are easier to evade.

Finally, our results suggest that enforcement strategies based on third-party reported information are complementary to the effectiveness of the tax authority's traditional auditing resources. While the immediate impact of enforcement strategies based on thirdparty information may be reduced through offsetting behavior, misreporting is channeled onto a smaller number of margins. This allows tax authorities to focus their (scarce) auditing resources on the margins that are more difficult to monitor through third-party information, rather than having to manually audit all margins. As the scope of transactions covered by third-party information grows, manual auditing can be focused on an increasingly narrow set of hard-to-monitor transactions. However, given the "weakest link" dynamic, it remains crucial to audit transactions that are hardest to monitor by

\footnotetext{
${ }^{25}$ Such spillovers are consistent with the findings in Pomeranz (2013).
} 
third-party information. Despite the growth of computer-based monitoring methods using cross-checks of third-party information, strengthening the auditing and enforcement capacity of developing country governments therefore still remains of crucial importance for effective tax collection. 


\section{References}

Allingham, Michael G. and Agnar Sandmo, "Income Tax Evasion: A Theoretical Analysis," Journal of Public Economics, 1972, 1 (3-4), 323-338.

Almunia, Miguel and David Lopez-Rodriguez, "Firms' Responses to Tax Enforcement Strategies: Evidence from Spain," Working Paper, University of Warwick, 2013.

Aparicio, Gabriela, Paul E. Carrillo, and M. Shahe Emran, "Taxes, Prisons, and CFOs: The Effects of Increased Punishment on Corporate Tax Compliance in Ecuador," Working Paper, The George Washington University, Institute for International Economic Policy, 2011.

Becker, Gary S., "Crime and Punishment:An Economic Approach," Journal of Political Economy, 1968, 76, 169-217.

Besley, Tim and Torsten Persson, "Taxation and Development," in A. J. Auerbach, R. Chetty, M. S. Feldstein, and E. Saez, eds., Handbook of Public Economics, Volume 5, 2013.

Best, Michael C., "Salary Misreporting and the Role of Firms in Workers Responses to Taxes: Evidence From Pakistan," Working Paper, London School of Economics, 2014.

_, Anne Brockmeyer, Henrick J. Kleven, Johannes Spinnewijn, and Mazhar Waseem, "Production vs Efficiency With Limited Tax Capacity: Theory and Evidence from Pakistan," Journal of Political Economy, forthcoming.

De Paula, Aureo and Jose A. Scheinkman, "Value-Added Taxes, Chain Effects, and Informality," American Economic Journal: Macroeconomics, 2010, 2 (4), 195-221.

Gillitzer, Christian and Peer E. Skov, "Evidence on Unclaimed Charitable Contributions from the Introduction of Third-Party Information Reporting in Denmark," Working Paper, Economic Policy Research Unit (EPRU), University of Copenhagen, 2013.

Gordon, Roger H. and Wei Li, "Tax Structures in Developing Countries: Many Puzzles and a Possible Explanation," Journal of Public Economics, 2009, 93 (7-8), 855-866.

Holmstrom, Bengt and Paul Milgrom, "Multitask Principal-Agent Analyses: Incentive Contracts, Asset Ownership, and Job Design," Journal of Law, Economics, and Organization, 1991, 7, 24.

Keen, Michael and Stephen Smith, "VAT Fraud and Evasion: What Do We Know and What Can Be Done?," National Tax Journal, 2006, 59 (4).

Klepper, Steven and Nagin Daniel, "The Anatomy of Tax Evasion," Journal of Law, Economics, and Organization, 1989, 5 (1), 1-24.

Kleven, Henrik J., Claus T. Kreiner, and Emmanuel Saez, "Why Can Modern Governments Tax So Much? An Agency Model of Firms As Fiscal Intermediaries," NBER Working Paper No. 15218, 2009. 
_, Martin Knudsen, Claus T. Kreiner, Soren L. Pedersen, and Emmanuel Saez, "Un-willing or Unable to Cheat? Evidence from a Tax Audit Experiment in Denmark," Econometrica, 2010, 79 (3), 651-692.

Kopczuk, Wojciech, "Polish Business Flat Tax and its Effect on Reported Incomes: a Pareto Improving Tax Reform?," Working Paper, Columbia University, 2012.

_ and Joel Slemrod, "Putting Firms into Optimal Tax Theory," The American Economic Review: Papers and Proceedings, 2006, 96 (2), 130-134.

Kremer, Michael, "The O-Ring Theory of Economic Development," The Quarterly Journal of Economics, 1993, 108 (3), 551-575.

Kumler, Todd J., Eric A. Verhoogen, and Judith Frías, "Enlisting Employees in Improving Payroll-Tax Compliance: Evidence from Mexico," NBER Working Paper No. 19385, 2013 .

Lewis-Faupel, Sean C., Yusuf Neggers, Ben Olken, and Rohini Pande, "Can Electronic Procurement Improve Infrastructure Provision? Evidence from Public Works in India and Indonesia," NBER Working Paper No. 20344, 2014.

Long, Susan B. and Judyth A. Swingden, "The Role of Third-Party Information Reporting and Compliance," in "Research Conference Report, How Do We Affect Taxpayer Behavior?, Internal Revenue Service Document 7302 (3-91)," Washington, D.C., 1990.

Muralidharan, Karthik, Paul Niehaus, and Sandip Sukhtankar, "Building State Capacity: Evidence from Biometric Smartcards in India," NBER Working Paper No. 19999, 2014 .

Naritomi, Joana, "Consumers as Tax Auditors," Working Paper, London School of Economics, 2013.

OECD, "Tax Administration in OECD and Selected Non-OECD countries: Comparitive Information Series 2010," Center for Tax Policy and Administration, Organization for Economic Cooperation and Development, 2011.

Pomeranz, Dina, "No Taxation Without Information: Deterrence and Self-Enforcement in the Value Added Tax," NBER Working Paper No. 19199, 2013.

Sanchez, Gonzalo E., "The Impact of Low-Cost Intervention on Tax Compliance: Regression Discontinuity Evidence," Working Paper, Texas A 85 M University, 2014.

Skinner, Jonathan and Joel Slemrod, "An Economic Perspective on Tax Evasion," National Tax Journal, 1985, pp. 345-353.

Slemrod, Joel, "Does It Matter Who Writes the Check to the Government? The Economics of Tax Remittance," National Tax Journal, 2008, 61 (2), 75-251.

_ , Brett Collins, Jeffrey Hoopes, Daniel Reck, and Michael Sebastiani, "Does Credit- 
Card Information Reporting Improve Small-Business Tax Compliance," Working Paper, 2014.

U.S. Government Accountability Office, "Tax Administration: Comparison of the Reported Tax Liabilities of Foreign-and U.S.-Controlled Corporations, 1998-2005," Report to Congressional Requesters GAO-08-957 2008.

World Bank, "Information and Communication Technology (ICT) for Greater Development Impact : World Bank Group strategy for ICT," 2012.

Yang, Dean, "Can Enforcement Backfire? Crime Displacement in the Context of Customs Reform in the Philippines," The Review of Economics and Statistics, 2008, 90 (1), 1-14.

Yitzhaki, Shlomo, "Income Tax Evasion: A Theoretical Analysis," Journal of Public Economics, 1974, 3 (2), 201-202. 


\section{Tables and Figures}

Table 1

Descriptive Statistics, All Firms, 2008-2010

\begin{tabular}{lc}
\hline \hline Revenue $(\$ 000)$ & 1,576 \\
& $(42,169)$ \\
Costs $(\$ 000)$ & {$[46]$} \\
& 1,475 \\
Tax liability (\$000) & {$[41,560)$} \\
& {$[46]$} \\
& 23 \\
For 2009-2010 only & $(626)$ \\
Reported revenue - third-party revenue $(\$ 000)$ & {$[0]$} \\
& \\
Reported costs - third-party costs $(\$ 000)$ & 536 \\
& {$[13,505)$} \\
\% of firms with positive third-party costs & 678 \\
Number of firms & $(26,861)$ \\
\hline \hline
\end{tabular}

Notes: Group means are reported along with standard deviations in parentheses and medians in brackets. All monetary figures in USD. 
Table 2

Descriptive Statistics By Year, Notified and Amending Firms

\begin{tabular}{|c|c|c|c|}
\hline & & Fiscal Year & \\
\hline & 2008 & 2009 & 2010 \\
\hline Panel A: Notified Firms & & & \\
\hline Revenue $(\$ 000)$ & 1,542 & 624 & 592 \\
\hline & $(6,118)$ & $(1,260)$ & $(1,237)$ \\
\hline & {$[136]$} & {$[120]$} & {$[103]$} \\
\hline Costs $(\$ 000)$ & 1,439 & 583 & 552.0 \\
\hline & $(5,398)$ & $(1,170)$ & $(1,153)$ \\
\hline & {$[129]$} & {$[113]$} & {$[96]$} \\
\hline Tax liability $(\$ 000)$ & 26 & 11 & 10 \\
\hline & $(171)$ & $(31.0)$ & $(27.6)$ \\
\hline & {$[1]$} & {$[1]$} & {$[1]$} \\
\hline Reported revenue - third-party revenue $(\$ 000)$ & -307 & -176 & -197 \\
\hline & $(1,741)$ & $(312)$ & $(388)$ \\
\hline & {$[-42]$} & {$[-64]$} & {$[-66]$} \\
\hline Observations & 3,136 & 2,221 & 2,636 \\
\hline $\begin{array}{l}\text { Number of firms with } \\
\text { invalid email addresses }\end{array}$ & - & 159 & 163 \\
\hline Panel B: Amending Firms & & & \\
\hline Revenue $(\$ 000)$ & 1,402 & 370 & 417 \\
\hline & $(4,367)$ & $(944)$ & $(959)$ \\
\hline & {$[179]$} & {$[56]$} & {$[34]$} \\
\hline Costs $(\$ 000)$ & 1,331 & 352 & 397 \\
\hline & $(4,172)$ & $(887)$ & $(923)$ \\
\hline & {$[163]$} & {$[62]$} & {$[33]$} \\
\hline Tax liability $(\$ 000)$ & 18 & 5 & 5 \\
\hline & $(70)$ & $(17)$ & $(13)$ \\
\hline & {$[1]$} & {$[0]$} & {$[0]$} \\
\hline Reported revenue - third-party revenue $(\$ 000)$ & -217 & -151 & -173 \\
\hline & $(806)$ & $(299)$ & $(333)$ \\
\hline & {$[-40]$} & {$[-55]$} & {$[-63]$} \\
\hline Observations & 596 & 249 & 421 \\
\hline Start of notification period & August 11, 2011 & March 26, 2012 & March 26, 2012 \\
\hline End of notification period & - & April 20, 2012 & April 20, 2012 \\
\hline
\end{tabular}


Table 3

Treatment Effects and Robustness Tests for Adjusting Firms:

Revenue and Cost Matching

\begin{tabular}{lcccc}
\hline \hline Specification: & Coefficient & (SE) & $N$ & $R^{2}$ \\
\hline $\begin{array}{l}\text { Panel A: Regressing Revenue Adjustment on } \\
\text { Revenue Discrepancy (2009-2010) }\end{array}$ & & & \\
Baseline (Corresponds to Figure 4B) & $0.927^{* * *}$ & $(0.105)$ & 570 & 0.728 \\
Robustness Tests & & & & \\
$\quad$ Only firms notified in no more than one round & $1.016^{* * *}$ & $(0.094)$ & 410 & 0.798 \\
$\quad$ Censoring to revenue discrepancies $<\$ 1,000,000$ & $0.900^{* * *}$ & $(0.112)$ & 556 & 0.623 \\
$\quad$ Censoring to revenue discrepancies $<\$ 250,000$ & $0.917^{* * *}$ & $(0.052)$ & 495 & 0.657 \\
$\quad$ Including negative revenue adjustments & $0.926^{* * *}$ & $(0.105)$ & 580 & 0.285 \\
$\quad$ SRI letter measure of baseline $\widehat{R}$ & $0.932^{* * *}$ & $(0.098)$ & 571 & 0.744 \\
$\quad$ Using only unadjusted variation in $R_{T}$ & $1.111^{* * *}$ & $(0.151)$ & 249 & 0.811 \\
\hline Panel B: Regressing Cost Adjustment on & & & & \\
Revenue Adjustment (2008-2010) & & & \\
Baseline (Corresponds to Figure 5$)$ & $0.962^{* * *}$ & $(0.016)$ & 979 & 0.982 \\
Robustness Tests & & & & \\
$\quad$ Only firms notified in no more than one round & $0.960^{* * *}$ & $(0.017)$ & 737 & 0.983 \\
$\quad$ Censoring to revenue adjustments $<\$ 1,000,000$ & $0.975^{* * *}$ & $(0.029)$ & 960 & 0.882 \\
$\quad$ Censoring to revenue adjustments $<\$ 250,000$ & $0.897^{* * *}$ & $(0.042)$ & 886 & 0.677 \\
$\quad$ Including negative revenue adjustments & $0.974^{* * *}$ & $(0.015)$ & 1,016 & 0.988 \\
$\quad$ SRI letter measure of baseline $\widehat{R}$ & $0.942^{* * *}$ & $(0.022)$ & 1,054 & 0.962 \\
\hline \hline
\end{tabular}

Notes: Panel A shows linear regressions of revenue adjustments on revenue discrepancies for adjusting firms in 2009 and 2010. Panel B shows linear regressions of cost adjustments on revenue adjustments for adjusting firms in 2008-2010. All monetary figures in USD. Standard errors clustered by firm in parentheses. Level of significance: ${ }^{* * *} p<0.01,{ }^{* *} p<0.05,{ }^{*} p<0.1$. 
Table 4

Treatment Effects on Overall Revenues, Costs, and Tax Liabilities, 2008-2010

\begin{tabular}{lccc}
\hline \hline & $(1)$ & $(2)$ & $(3)$ \\
& Revenue & Costs & Tax \\
& & & Liability \\
\hline Panel A: Amending Firms & & & \\
Post & $86,203^{* * *}$ & $80,155^{* * *}$ & $1,857^{* * *}$ \\
& $(15,346)$ & $(15,037)$ & $(222)$ \\
Constant & $871,286^{* * *}$ & $827,971^{* * *}$ & $11,237^{* * *}$ \\
& $(7,673)$ & $(7,518)$ & $(111)$ \\
Firm FE & Yes & Yes & Yes \\
$R^{2}$ & 0.996 & 0.995 & 0.996 \\
\hline Observations & 2,532 & 2,532 & 2,532 \\
Number of firms & 1,175 & 1,175 & 1,175 \\
\hline Panel B: Notified Firms & & & \\
Post & $13,653^{* * *}$ & $12,695^{* * *}$ & $294^{* * *}$ \\
& $(2,363)$ & $(2,310)$ & $(35)$ \\
Constant & $973,367^{* * *}$ & $908,564^{* * *}$ & $16,224^{* * *}$ \\
& $(1,181)$ & $(1,155)$ & $(17)$ \\
Firm FE & Yes & Yes & Yes \\
$R^{2}$ & 0.998 & 0.998 & 0.998 \\
\hline Observations & 15,986 & 15,986 & 15,986 \\
Number of firms & 6,532 & 6,532 & 6,532 \\
\hline \hline
\end{tabular}

Notes: Dependent variables are in levels. All monetary figures in USD. Standard errors clustered by firm in parentheses. Level of significance: ${ }^{* * *} p<0.01,{ }^{* *} p<0.05,{ }^{*} p<0.1$. 
Table 5

Placebo Tests: Simulated Treatment Effects for Non-Notified Firms, 2008-2010

\begin{tabular}{lccc}
\hline \hline & $(1)$ & $(2)$ & $(3)$ \\
& Revenue & Costs & $\begin{array}{c}\text { Tax } \\
\text { Liability }\end{array}$ \\
\hline Panel A: All Non-Notified Firms & & & \\
Post & 1,820 & $-1,524$ & 546 \\
& $(1,616)$ & $(2,417)$ & $(598)$ \\
Constant & $1,488,306^{* * *}$ & $1,393,331^{* * *}$ & $22,099^{* * *}$ \\
& $(811)$ & $(1,214)$ & $(299)$ \\
Firm FE & Yes & Yes & Yes \\
$R^{2}$ & 0.848 & 0.836 & 0.856 \\
\hline Observations & 400,128 & 400,128 & 401,482 \\
Number of firms & 90,264 & 90,264 & 90,264 \\
\hline Panel B: Amending Non-Notified Firms & & & \\
Post & 304,909 & $-225,026$ & 86,403 \\
& $(308,155)$ & $(461,319)$ & $(114,806)$ \\
Constant & $9,535,873^{* * *}$ & $9,370,717^{* * *}$ & $36,668^{* * *}$ \\
& $(158,031)$ & $(236,578)$ & $(58,876)$ \\
Firm FE & Yes & Yes & Yes \\
$R^{2}$ & 1.000 & 0.999 & 0.513 \\
\hline Observations & 2,611 & 2,611 & 2,611 \\
Number of firms & 1,230 & 1,230 & 1,230 \\
\hline \hline
\end{tabular}

Notes: Linear regressions for non-notified firms, supposing that they had been notified on the first day of the notification period for each year. Panel A displays all non-notified firms, Panel B non-notified firms that happened to amend during the relevant period. All monetary figures in USD. Standard errors clustered by firm in parentheses. Level of significance: ${ }^{* * *} p<0.01$, ${ }^{* *} p<0.05,{ }^{*} p<0.1$. 
Figure 1

Amendment Rates
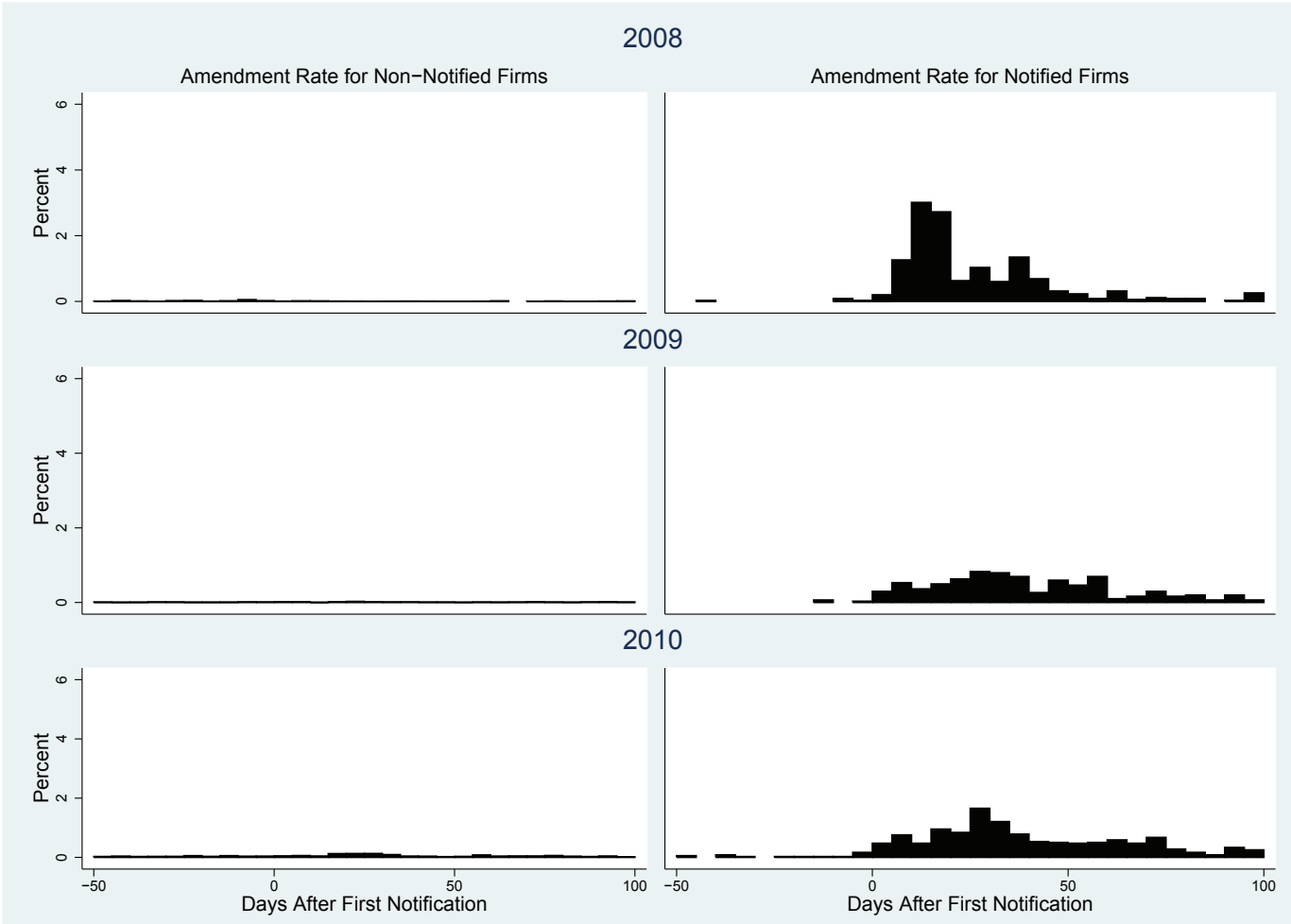

Notes: The left Column plots amendment rates for the universe of non-notified firms before and after the start of the intervention. The right Column does the same for notified firms. Start date imputed for 2008 (see text for details). 


\section{Figure 2}

Revenue and Cost Discrepancies, All Firms with Positive Third-Party Information

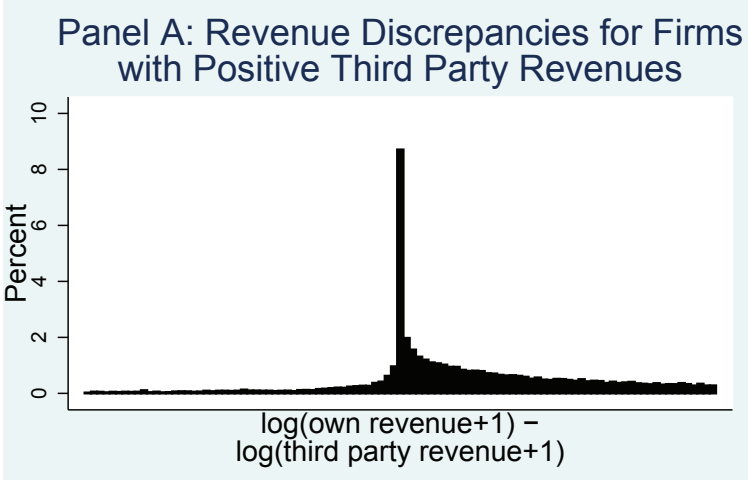

Panel B: Cost Discrepancies for Firms with Positive Third Party Costs

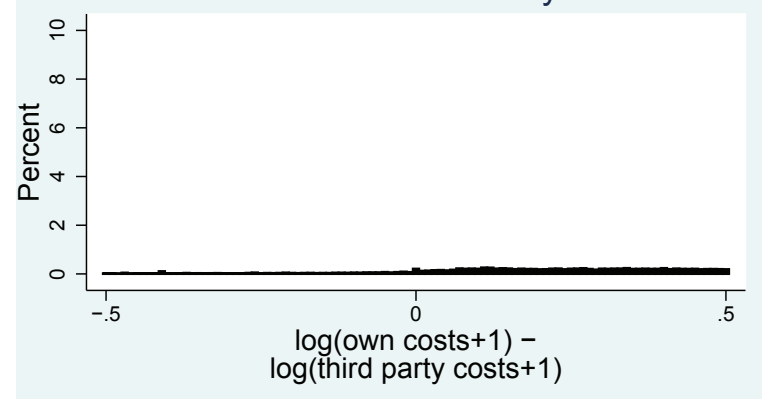

Notes: Results are shown for the sample of 59,937 active firms for which there are positive third-party revenues in Panel A and the sample of 74,519 active firms for which there are positive third-party costs in Panel B. Both panels show data for 2009-2010, the years for which complete third-party information is available. Results are similar if histograms are separated by year. Bins are of size 0.01, and the top and bottom $1 \%$ of the sample are omitted when calculating bin heights for computational purposes. $3.8 \%$ of reports match revenues exactly; $0.1 \%$ match costs exactly. 
Figure 3

Revenue Adjustments among Amending Firms
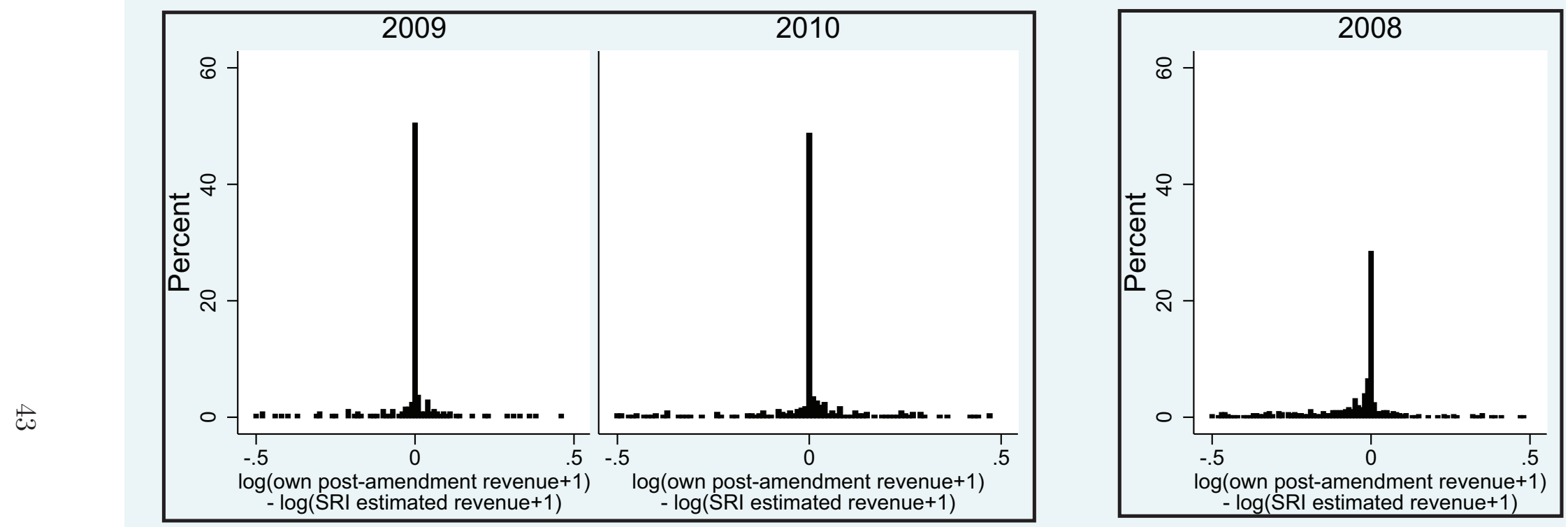

Notes: Bins are of size 0.01 , and the top and bottom $1 \%$ of the sample are omitted when calculating bin heights for computational purposes. $39 \%$ of firms match exactly in 2009; $35 \%$ matched exactly in 2010; $6 \%$ matched exactly in 2008. 
Figure 4

Revenue Matching

Panel A: Amending Firms
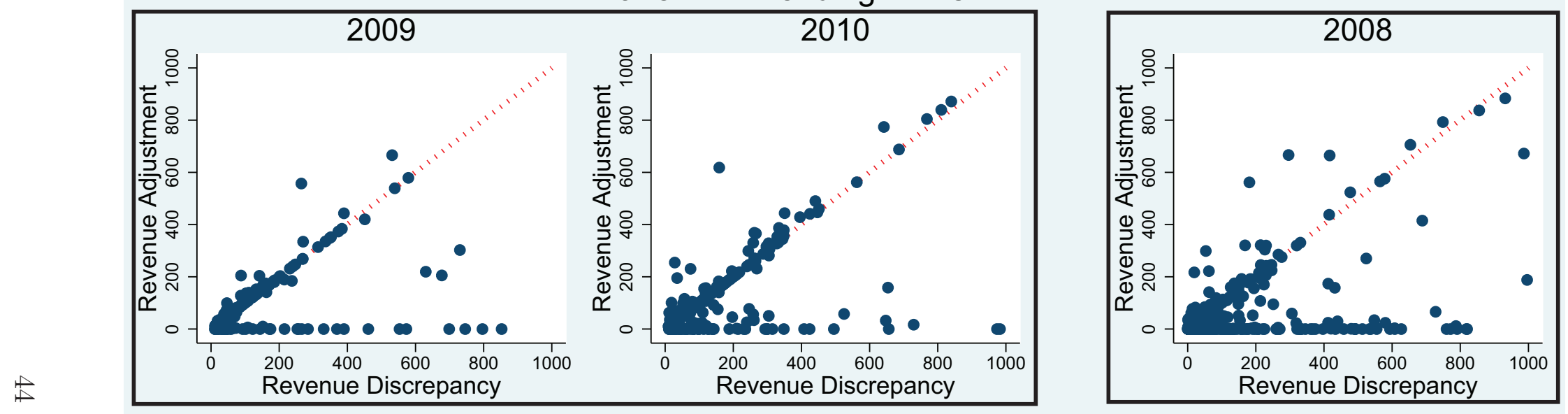

Panel B: Adjusting Firms
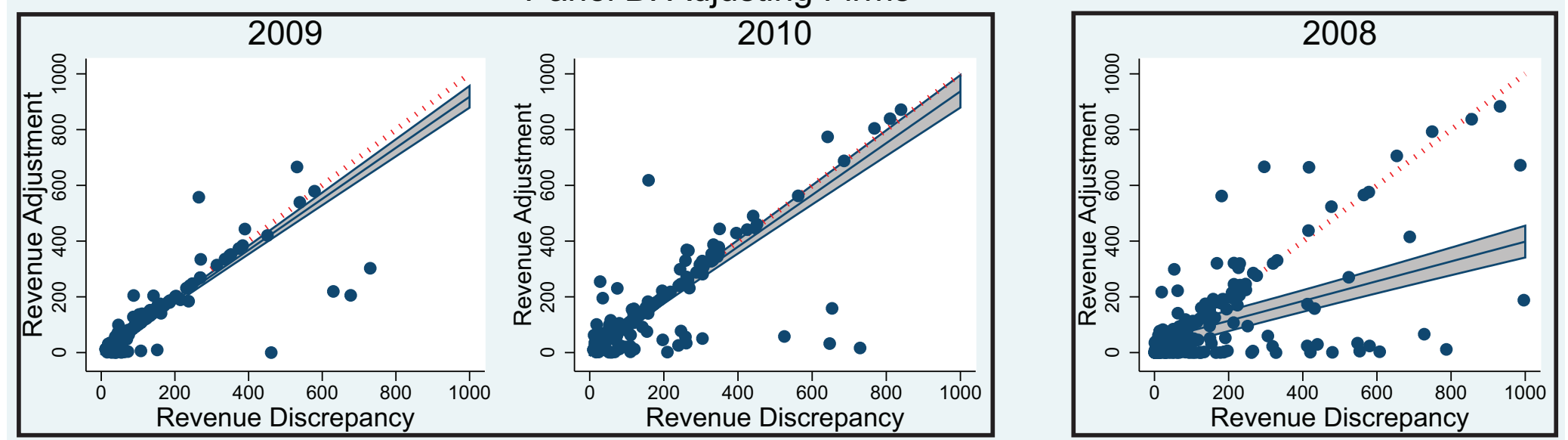

Notes: The dashed line indicates a 45-degree line. Also shown is a fitted line, and a 95\% confidence interval for the fitted line. Axes are restricted to show zero to one million but the fitted line and confidence interval reflect the unrestricted sample. Axes are in thousands of USD. Slopes are as follows: 0.916 for the 2009 round, 0.930 for the 2010 round, and 0.355 for the 2008 round. 
Figure 5

Cost Matching
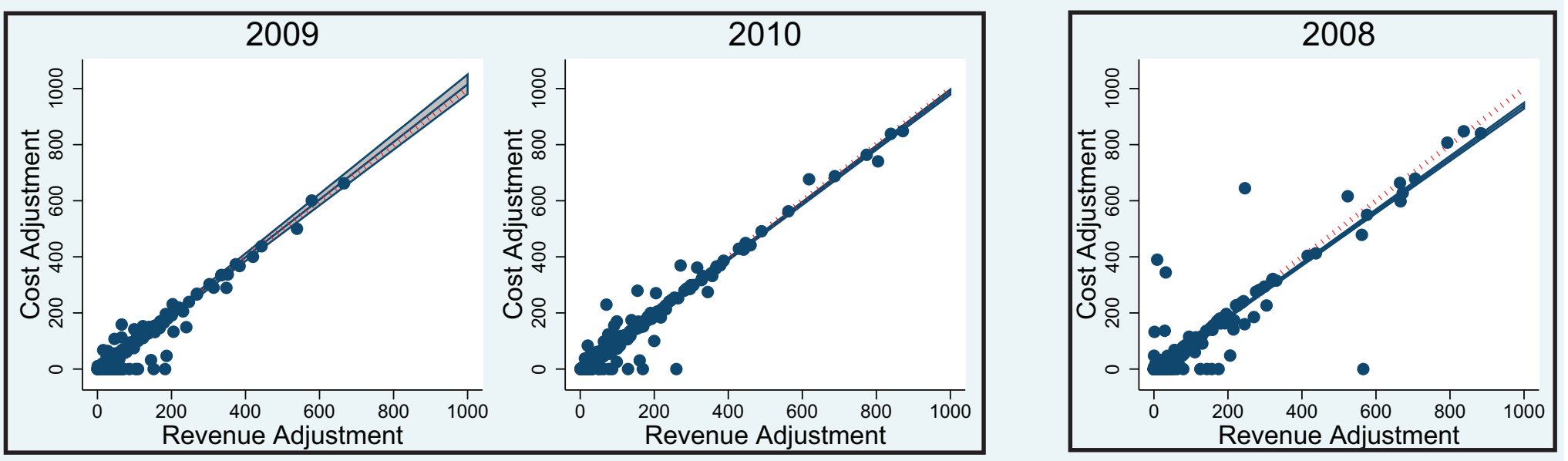

Notes: The dashed line indicates a 45-degree line. Also shown is a fitted line, and a 95\% confidence interval for the fitted line. Axes are restricted to show zero to one million but the fitted line and confidence interval reflect the unrestricted sample. Axes are in thousands of USD. Slopes are as follows: 1.028 for the 2009 round, 0.993 for the 2010 round, and 0.942 for the 2008 round. 
Figure 6

Changes in Taxes Among Adjusting Firms

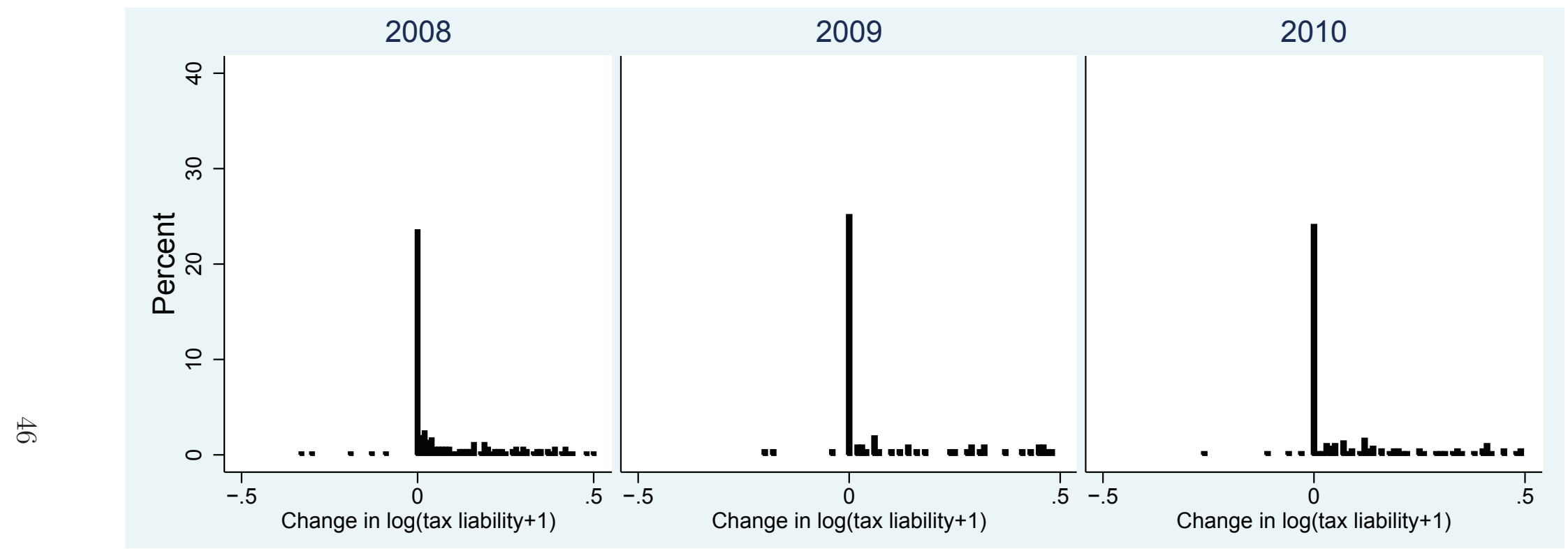

Notes: Histograms of the change in $\log (\operatorname{tax}$ liability +1$)$ between pre- and post-notification for amending firms that made a positive revenue adjustment. Bins are of size 0.01 , and the bottom $1 \%$ of the sample is omitted when calculating bin heights for computational reasons. 


\section{Appendix}

\section{Appendix A1: Additional Tables and Figures}

Table A1

Treatment Effects in Subsequent Filings

\begin{tabular}{lccc}
\hline \hline & $(1)$ & $(2)$ & $(3)$ \\
& Revenue & Costs & $\begin{array}{c}\text { Tax } \\
\text { Liability }\end{array}$ \\
\hline Treated $\times$ Post & $539,247^{* * *}$ & $468,812^{* *}$ & $10,326^{* * *}$ \\
& $(120,942)$ & $(118,065)$ & $(3,697)$ \\
Post & $225,061^{* * *}$ & $225,252^{* * *}$ & $2,723^{*}$ \\
& $(56,766)$ & $(59,756)$ & $(1,600)$ \\
Constant & $1,859,045^{* * *}$ & $1,733,198^{* * *}$ & $30,237^{* * *}$ \\
& $(17,656)$ & $(16,918)$ & $(549)$ \\
Firm FE & Yes & Yes & Yes \\
$R^{2}$ & 0.955 & 0.950 & 0.864 \\
\hline Observations & 11,675 & 11,675 & 11,675 \\
Number of firms & 3,081 & 3,081 & 3,081 \\
\hline \hline
\end{tabular}

Notes: Linear regressions for firms selected to be notified in the 2008 round. Treated firms are those that were actually notified; control firms are those that were not notified due to time constraints. All monetary figures in USD. Standard errors clustered by firm in parentheses. Level of significance: ${ }^{* * *} p<0.01,{ }^{* *} p<0.05,{ }^{*} p<$ 0.1 . 


\section{Figure A1}

Revenue and Cost Discrepancies, All Firms

(Includes Filings with Zero Third-Party Reports)

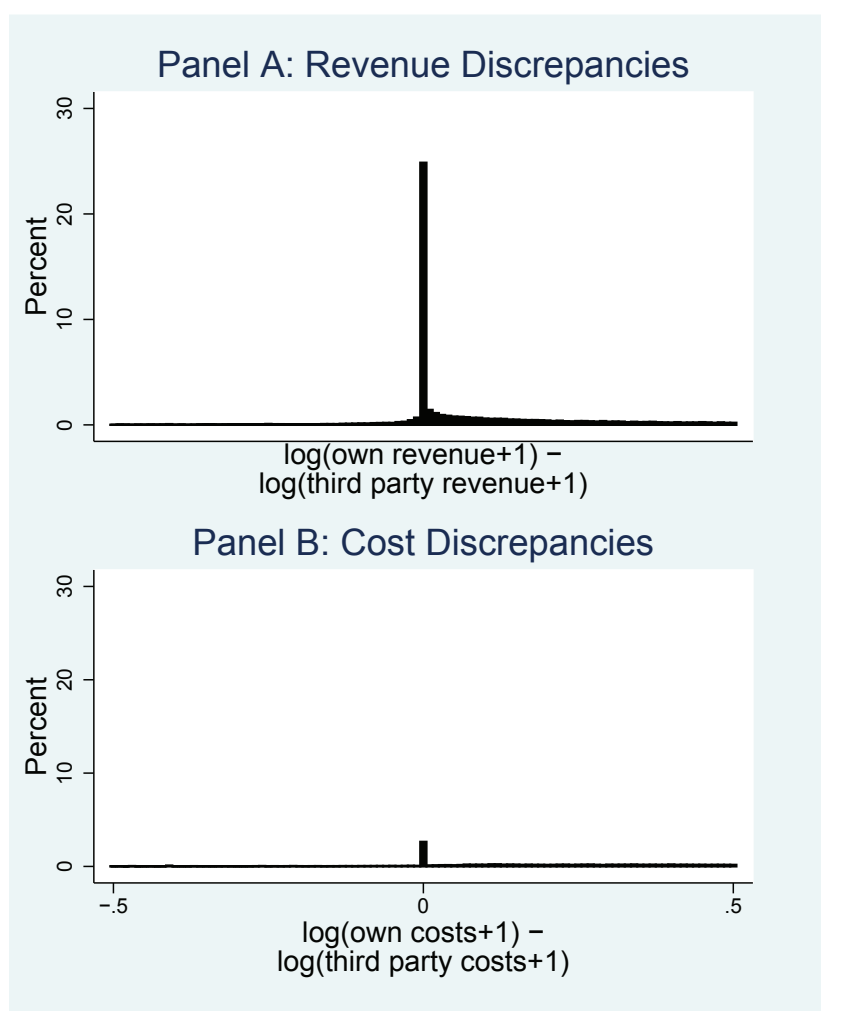

Notes: Results are shown for the entire sample of 82,774 active firms. Both panels show data for 20092010, since third-party costs are not available for 2008. Results are similar if histograms are separated by year. Bins are of size 0.01 , and the top and bottom $1 \%$ of the sample are omitted when calculating bin heights for computational reasons. $21.0 \%$ of reports match revenues exactly; $2.5 \%$ match costs exactly. 
Figure A2

Revenue Matching, Scaled by Baseline Reported Revenues
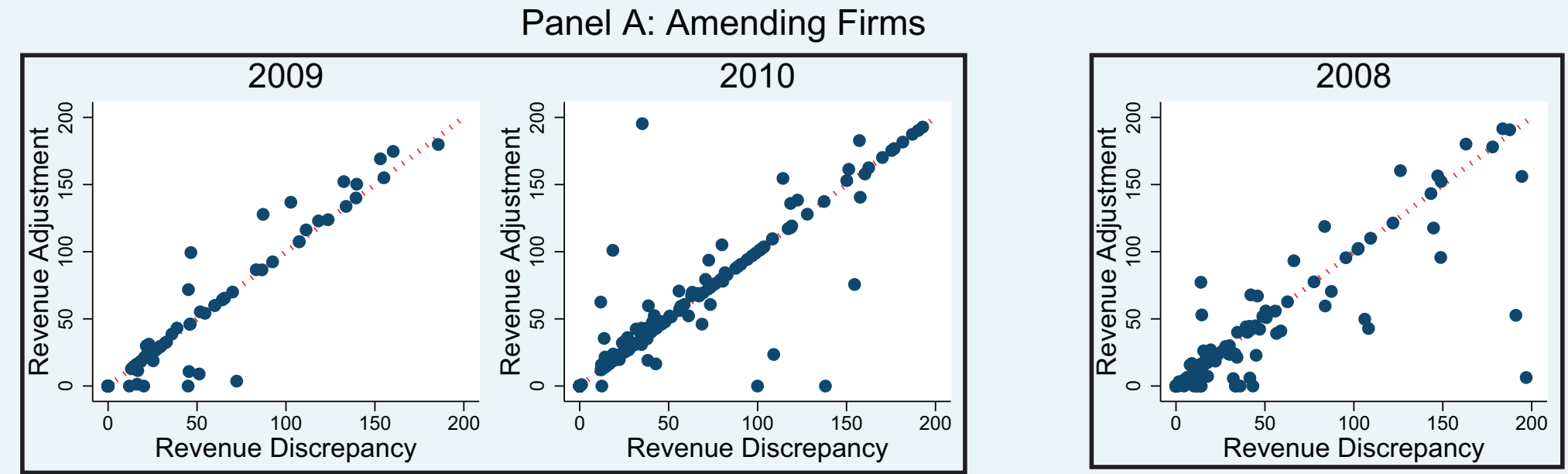

\section{Panel B: Adjusting Firms}
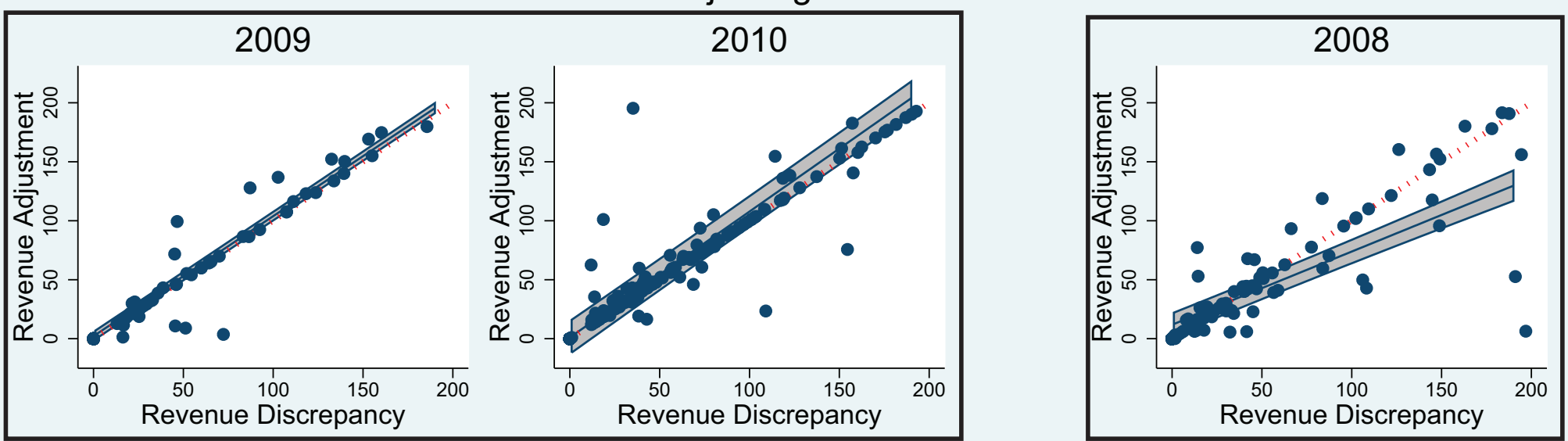

Notes: Variables are scaled by dividing by (pre-notification reported revenue +1 ). The dashed line indicates a 45 -degree line. Also shown is a fitted line, and a $95 \%$ confidence interval for the fitted line. Axes are in thousands of USD and are restricted to show zero to 200 thousand, but the fitted line and confidence interval reflect the unrestricted sample. Slopes are as follows: 1.017 for the 2009 round, 1.067 for the 2010 round, and 0.620 for the 2008 round. 
Figure A3

Cost Matching, Scaled by Baseline Reported Revenues
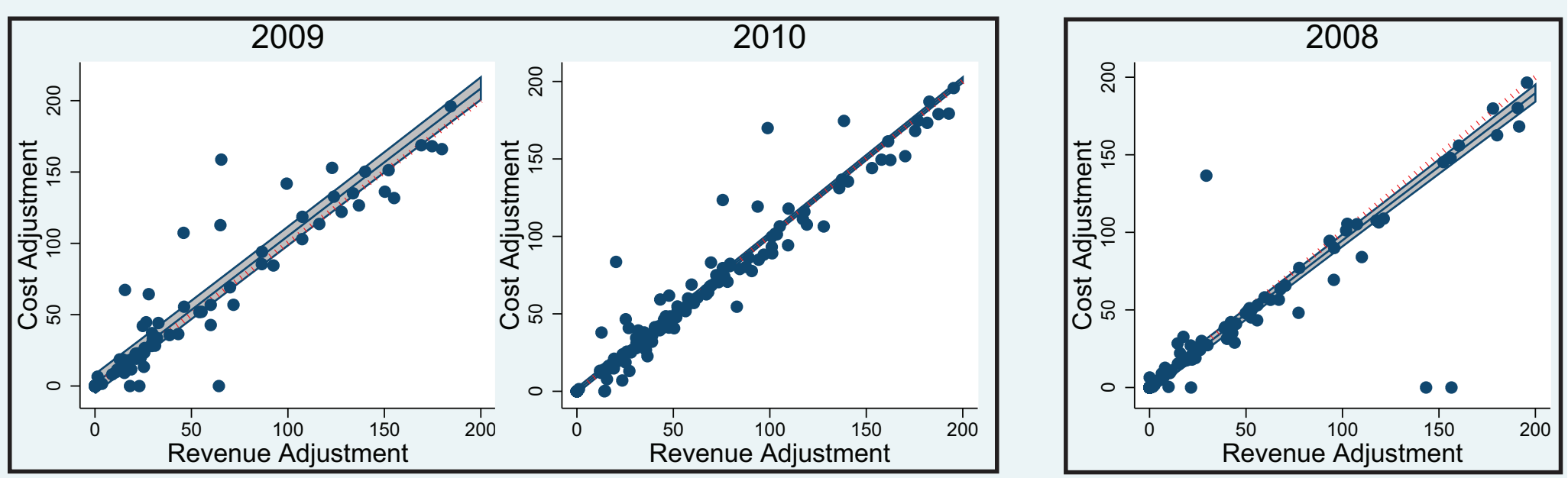

Notes: Variables are scaled by dividing both the variables on the $\mathrm{y}$ and $\mathrm{x}$-axis by (pre-notification reported revenue +1 ). The dashed line indicates a 45-degree line. Also shown is a fitted line, and a 95\% confidence interval for the fitted line. Axes are in thousands of USD and are restricted to show zero to 200 thousand but the fitted line and confidence interval reflect the unrestricted sample. Slopes are as follows: 1.035 for the 2009 round, 1.003 for the 2010 round, and 0.949 for the 2008 round. 
Figure A4

Mean Reported Revenues in Subsequent Filings

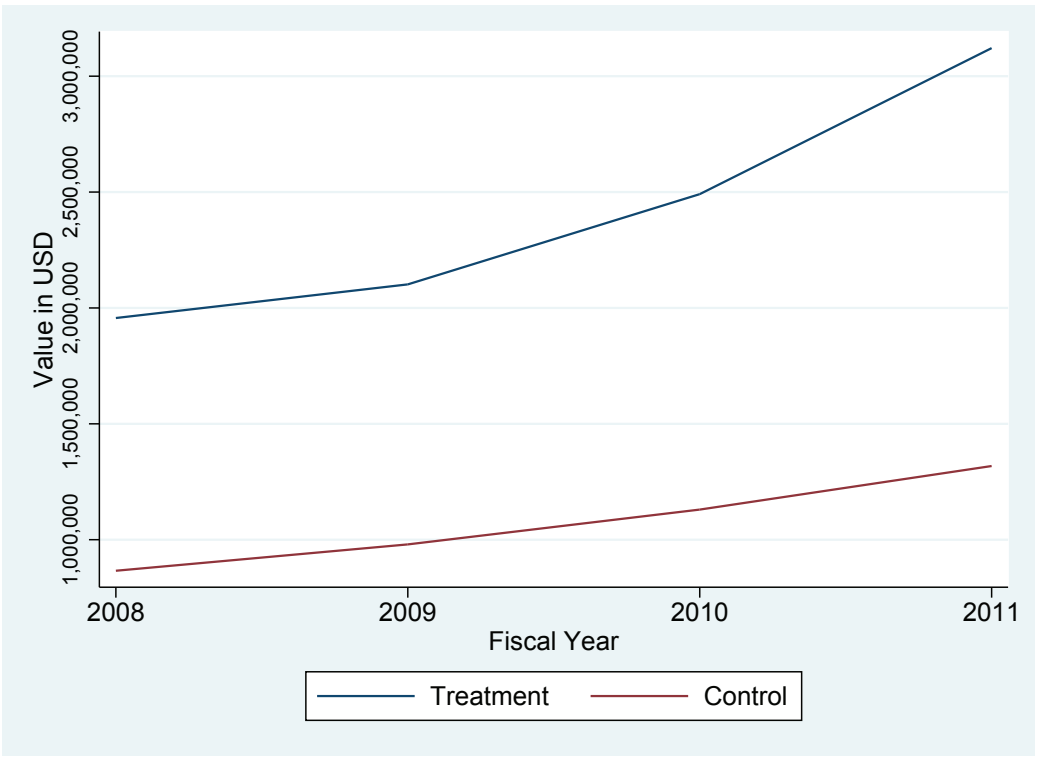

Notes: Lines show mean reported revenues by year for treatment firms (above) and control (below) firms. Treatment firms are those notified in the 2008 round. Control firms are those selected to be notified in the 2008 round but not actually notified due to time constraints. 
Figure A5

Mean Reported Costs in Subsequent Filings

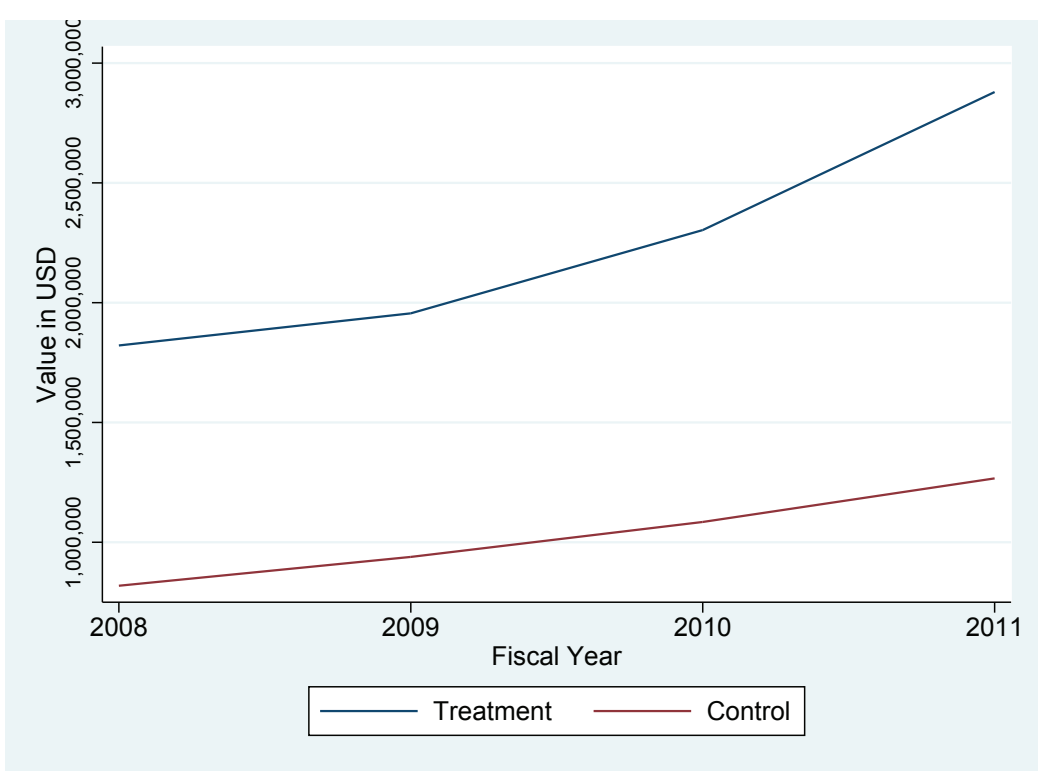

Notes: Lines show mean reported costs by year for treatment firms (above) and control (below) firms. Treatment firms are those notified in the 2008 round. Control firms are those selected to be notified in the 2008 round but not actually notified due to time constraints. 


\section{Appendix A2: Policy Intervention Message: Year 2008 \\ SERVICIO DE RENTAS INTERNAS \\ DEPARTAMENTO DE GESTIÓN TRIBUTARIA}

Quito, 5 de septiembre del 2011

Señor (a) $\operatorname{xxxxxx}$

Gerente General de xxxxx

El Art. 67 del Código Tributario y el segundo artículo de la Ley de Creación del Servicio de Rentas Internas otorgan a esta Administración Tributaria la facultad para efectuar la determinación, recaudación y control de los tributos internos del Estado.

Esta Administración Tributaria, luego de revisar las bases de datos con las que cuenta, ha identificado valores atribuibles a ingresos de la sociedad a la que usted representa superiores al monto registrado en la declaración de impuesto a la renta correspondiente al ejercicio fiscal 2008.

De conformidad a lo establecido por los artículos 89 del Código Tributario y 101 de la Ley de Régimen Tributario, las declaraciones de impuestos efectuadas por los sujetos pasivos tienen el carácter de definitivas y vinculantes, por lo que hacen responsable al declarante y, en su caso, al contador que firme la declaración, por la exactitud y veracidad de los datos que contenga; sin embargo el sujeto pasivo, a petición expresa del Servicio de Rentas Internas podrá, dentro de los seis años siguientes a la fecha de presentación de la declaración original, rectificar en una declaración sustitutiva, los rubros requeridos por la Administración Tributaria.

El Art. 19 de la Ley de Régimen Tributario Interno y el artículo 37 de su reglamento, establecen que todas las sociedades están obligadas a llevar contabilidad y declarar el impuesto en base a los resultados que arroje la misma. Adicionalmente los libros contables tienen que estar debidamente respaldados por los correspondientes comprobantes de venta y demás documentos pertinentes, documentación toda que puede ser requerida en cualquier momento por la Administración Tributaria para fines de control.

En atención a los antecedentes y a las normas legales citadas, esta Administración le 
solicita presente la declaración sustitutiva correspondiente al impuesto a la renta del ejercicio fiscal 2008 vía Internet, dentro de los diez (10) días hábiles posteriores a la presente comunicación.

Adicionalmente le recordamos que en la declaración del impuesto a la renta del año 2008, debe registrar el valor del anticipo calculado de impuesto a la renta con cargo al ejercicio fiscal 2009, de conformidad al artículo 41 de la Ley de Régimen Tributario Interno.

A la vez se le informa que de ser el caso, el sujeto pasivo, deberá calcular el impuesto, interés y multa a pagar considerando los pagos previos efectuados, conforme la normativa tributaria vigente respecto a la imputación al pago.

Finalmente, se advierte al sujeto pasivo que la Administración Tributaria se reserva el derecho de verificar oportunamente la información contenida en las declaraciones de impuestos, que en el caso de que el sujeto activo ejerza su facultad determinadora procederá a cobrar un recargo del veinte por ciento (20\%) calculado en base al impuesto determinado, y que en caso de comprobar la existencia de actos de ocultación o falsedad, por los que se haya dejado de pagar en todo o en parte los tributos debidos, en provecho propio o de un tercero, tales hechos se considerarán defraudación fiscal, conforme lo señala el artículo 342 del Código Tributario y cuyas sanciones se especifican en el Libro Cuarto del mismo cuerpo legal que se refiere al Ilícito Tributario.

En caso de requerir mayor información sobre la presente comunicación puede acercarse a las oficinas del Departamento de Gestión Tributaria, ubicadas a nivel nacional.

El envío de este correo es automático, por favor no lo responda.

Atentamente,

\section{Servicio de Rentas Internas}

Nota: Ahora es más fácil cumplir con sus obligaciones tributarias, utilizando nuestro servicio gratuito de declaraciones y anexos por internet, que le permitirá presentar ágilmente la información. Obtenga su clave de seguridad y el programa en cualquiera de las oficinas del Servicio de Rentas Internas a nivel nacional. 


\section{Appendix A3: Policy Intervention Message: Years 2009 - 2010}

\section{Declare correctamente su Impuesto a la Renta}

\section{SERVICIO DE RENTAS INTERNAS \\ DEPARTAMENTO DE GESTIÓN TRIBUTARIA}

Quito, a viernes, 20 de abril de 2012

Señor (a) xx

Representante Legal de xx

El Art. 67 del Código Tributario y el segundo artículo de la Ley de Creación del Servicio de Rentas Internas otorgan a esta Administración Tributaria la facultad para efectuar la determinación, recaudación y control de los tributos internos del Estado.

El Servicio de Rentas Internas, ha realizado el cruce especial de información donde se verifican los valores declarados en el rubro Ventas Gravadas y No Gravadas. Así, luego de revisar las bases de datos con las que cuenta, ha detectado valores atribuibles a la sociedad a la que usted representa, diferentes a los montos registrados en la declaración de impuesto a la renta correspondiente al ejercicio fiscal 20XX, según se puede observar en el siguiente detalle:

\begin{tabular}{|l|l|c|c|}
\hline $\begin{array}{l}\text { Año } \\
\text { Fiscal }\end{array}$ & $\begin{array}{l}\text { Casillero de la Declaración } \\
\text { de Impuesto a la Renta }\end{array}$ & $\begin{array}{l}\text { Valor calculado por la Ad- } \\
\text { ministración Tributaria }\end{array}$ & $\begin{array}{l}\text { Valor declarado por } \\
\text { el contribuyente }\end{array}$ \\
\hline 20XX & 699 - TOTAL INGRESOS & $777.499,10$ & $719.153,50$ \\
\hline
\end{tabular}


De conformidad a lo establecido por los artículos 89 del Código Tributario y 101 de la Ley de Régimen Tributario, las declaraciones de impuestos efectuadas por los sujetos pasivos tienen el carácter de definitivas y vinculantes, por lo que hacen responsables al declarante y al contador que firmen la declaración, por la exactitud y veracidad de los datos que contenga la misma; sin embargo el sujeto pasivo, a petición expresa del Servicio de Rentas Internas podrá, dentro de los seis años siguientes a la fecha de presentación de la declaración original, rectificar en una declaración sustitutiva, los rubros requeridos por la Administración Tributaria.

El Art. 19 de la Ley de Régimen Tributario Interno y el artículo 37 de su reglamento, establecen que todas las sociedades están obligadas a llevar contabilidad y declarar el impuesto en base a los resultados que arroje la misma. Adicionalmente los libros contables tienen que estar debidamente respaldados por los correspondientes comprobantes de venta y demás documentos pertinentes, documentación toda que puede ser requerida por la Administración Tributaria para fines de control.

En atención a los antecedentes y a las normas legales citadas, esta Administración le apremia a presentar la declaración sustitutiva correspondiente al impuesto a la renta del ejercicio fiscal 20XX vía Internet.

Adicionalmente se le recuerda que en la declaración del impuesto a la renta del año 20XX debe registrar el valor del anticipo calculado de impuesto a la renta con cargo al ejercicio fiscal 20XX, de conformidad al artículo 41 de la Ley de Régimen Tributario Interno.

De ser el caso, el sujeto pasivo deberá calcular el impuesto, interés y multa a pagar, considerando los pagos previos efectuados, conforme la normativa tributaria vigente respecto a la imputación al pago.

Finalmente, se informa al sujeto pasivo que la Administración Tributaria se reserva el derecho de verificar oportunamente la información contenida en las declaraciones de impuestos, y que en el caso de que el sujeto activo ejerza su facultad determinadora procederá cobrar un recargo del veinte por ciento $(20 \%)$ calculado en base al impuesto determinado; así como también, que en caso de comprobar la existencia de actos de ocultación o falsedad, por los que se haya dejado de pagar en todo o en parte los tributos debidos, en provecho propio o de un tercero, tales hechos se considerarán defraudación fiscal, conforme lo señala el artículo 342 del Código Tributario y cuyas sanciones se especifican en el Libro Cuarto 
del mismo cuerpo legal que se refiere al Ilícito Tributario.

La asesoría que se requiera para el cumplimiento de obligaciones tributarias, la puede obtener en todas las oficinas del Servicio de Rentas Internas a nivel nacional o a través de nuestra página web (www.sri.gob.ec).

Atentamente,

Servicio de Rentas Internas

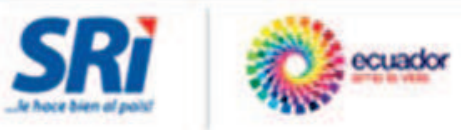

Cobusvo Nuconut be.

UNERALCADELCUADOF 